\title{
CULTURAL DEVELOPMENT OF THE PALLARS REGION (NE IBERIAN PENINSULA) FROM THE BRONZE AGE TO THE PRESENT
}

An English summary based on the Catalan book: Història del Pallars. Dels orígens als nostres dies, edited by C. M. Marugan and V. Rapalino (Pagès Editors, Lleida, 2005)

by

\section{Valentí Rull}

Botanic Institute of Barcelona (IBB)

Higher Council for Scientific Research (CSIC)

Passeig del Migdia s/n, 08038 Barcelona, Spain

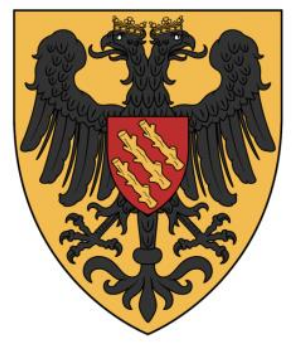

Barcelona, 13 June 2021

Note. This summary is exclusively for scientific purposes, without any commercial interests. 


\section{Index}

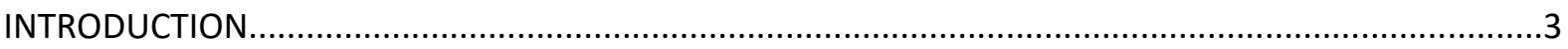

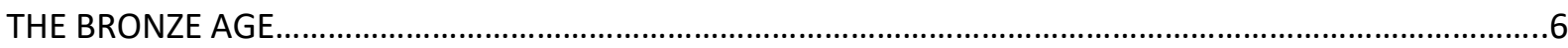

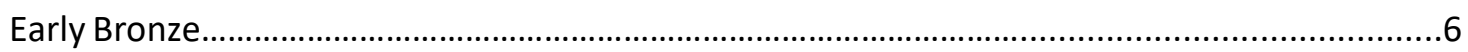

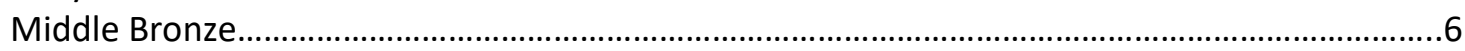

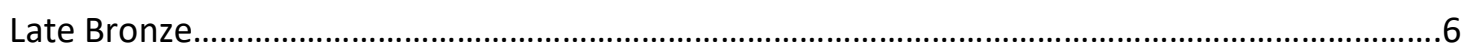

THE IRON AGE

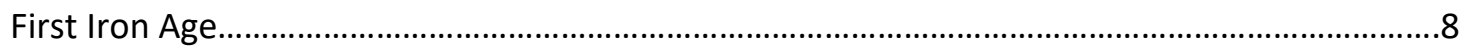

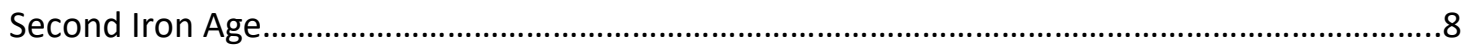

THE ROMAN EPOCH

Commercial activities..........................................................................................................

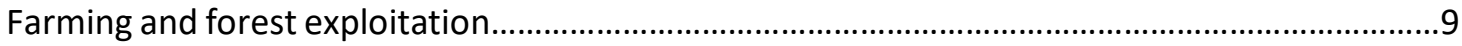

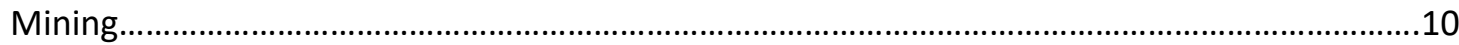

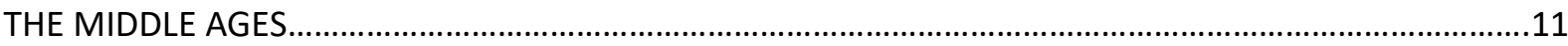

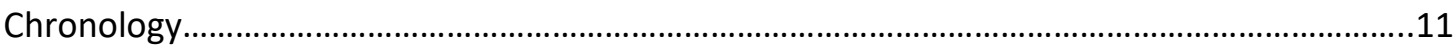

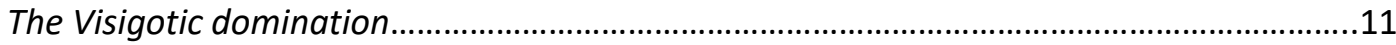

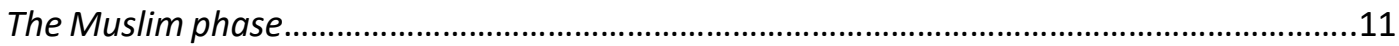

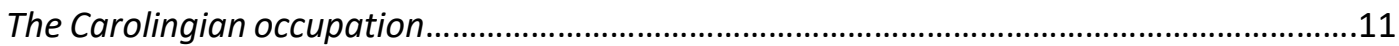

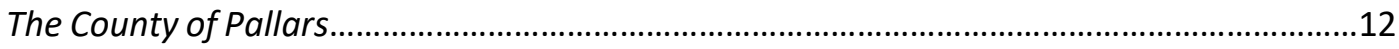

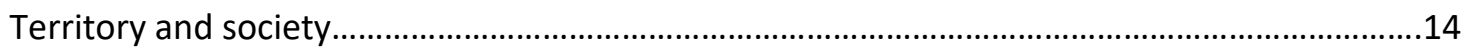

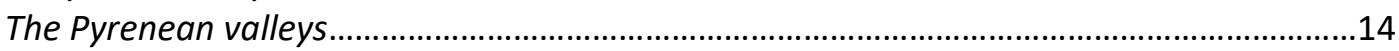

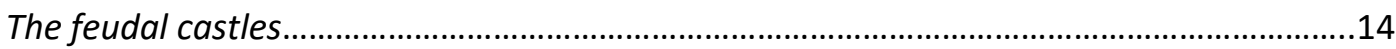

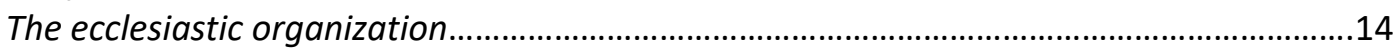

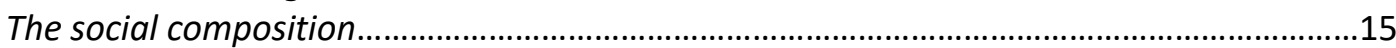

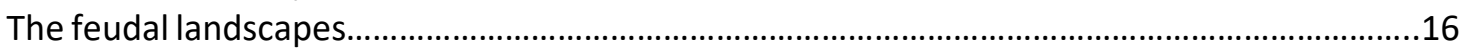

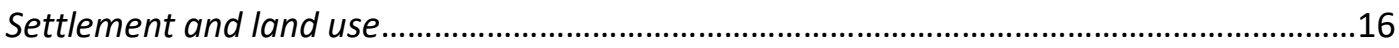

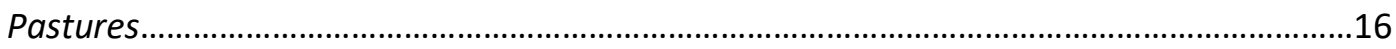

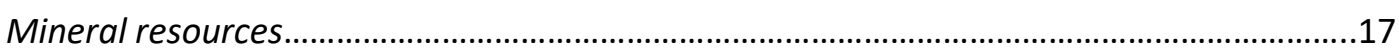

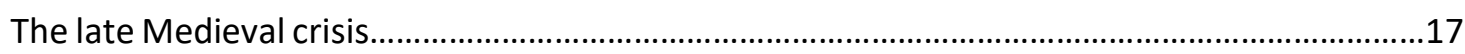

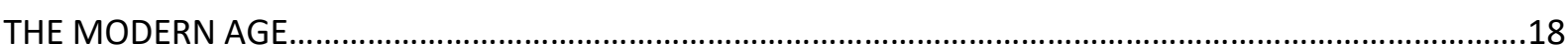

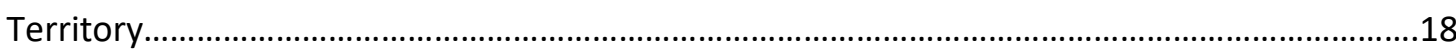

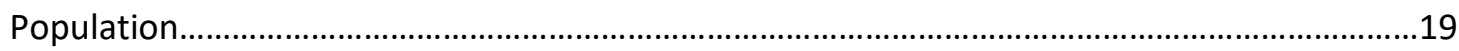

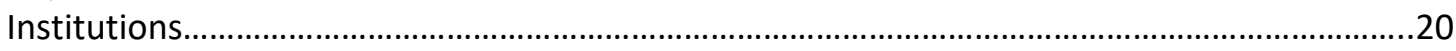

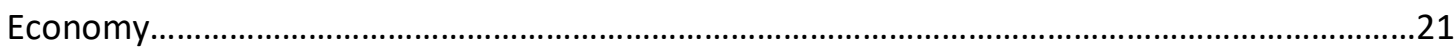

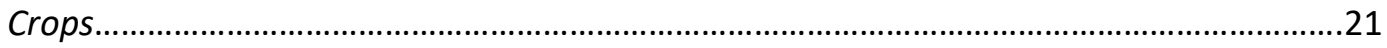

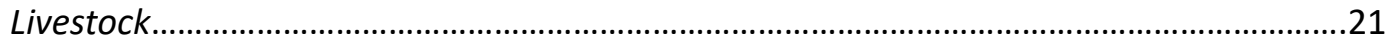

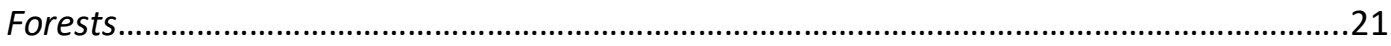

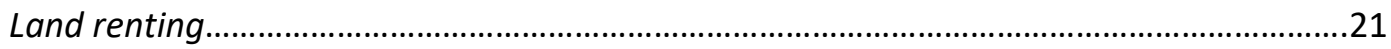

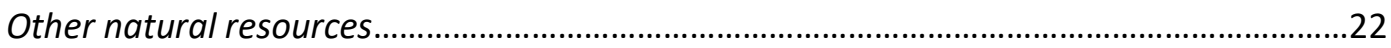

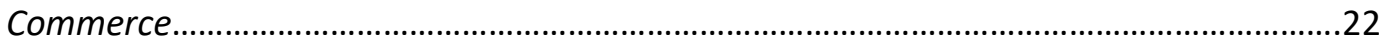

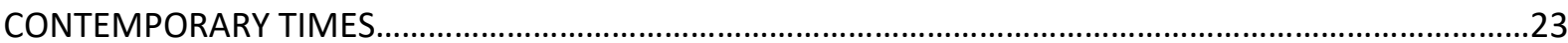

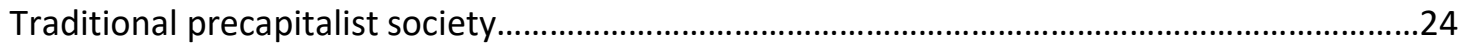

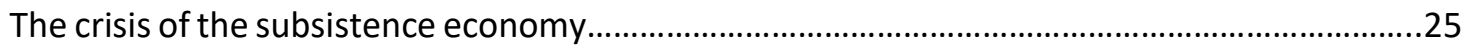

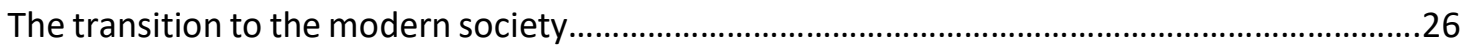

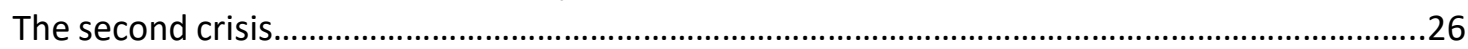

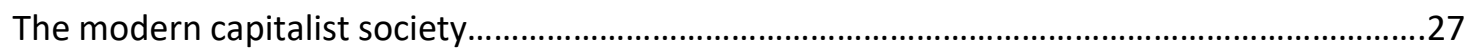

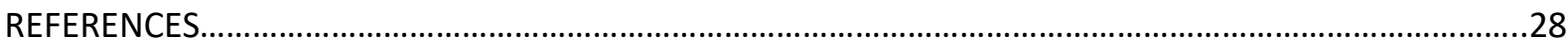




\section{INTRODUCTION}

The Pallars region, situated in the Spanish autonomous region of Catalonia, has experienced some changes over time but it has maintained a consistent geographical unity around the Medieval County of Pallars (872-1488 CE), which roughly coincided with the assemblage of present-day political subdivisions (comarques) called Pallars Jussá, Pallars Sobirà and Alta Ribagorça (Fig. 2). Orographically, the Pallars region ranges from the highest elevations of the Catalan Pyrenees (above $3000 \mathrm{~m}$ ), to the north, to basimontane levels (ca. $500 \mathrm{~m}$ ) to the south (Fig. 3). This elevational gradient is interrupted locally at the southernmost boundary of the Pallars region by the Montsec Range, a small and narrow mountain chain ( $40 \mathrm{~km}$ long and a few $\mathrm{km}$ wide), reaching an elevation of almost $1700 \mathrm{~m}$. The Pyrenean range is the natural boundary between Spain and France, and the Montsec Range is the boundary between the Pallars and the southern lowlands, ranging in elevation from 100 to $300 \mathrm{~m}$ (Fig. 3). The Pyrenean Pallars is the headwaters of the river Noguera Pallaresa, draining to the south until it flows into the Ebro river.

The cultural history of the Pallars region, where Lake Montcortès is located (Figs. 1 to 3 ), is relatively well known but is written mostly in Catalan, which makes access for an international audience difficult. Here an English summary is provided, based on the book edited by Marugan \& Rapalino (2005). The primary aim is to facilitate an understanding of discussions about vegetation and land-use dynamics over time, obtained after palynological analysis of Lake Montcortès sediments. Some illustrations have been added for more clarity. The present account begins in the Bronze Age, to be consistent with the chronological framework of the available vegetation reconstruction, which ranges from the Late Bronze Age (ca. 3050 BP or 1100 BCE) to the present (2013 CE) (Rull et al., 2011, 2021; Trapote et al., 2018). The protohistoric and historic chronology of the Pallars region is summarized in Fig. 4. This summary is not intended as a literal translation or an accurate English version of the original text and should be considered solely as the result of a personal reading and outlining by the author (with no reinterpretations), who is solely responsible for the content.

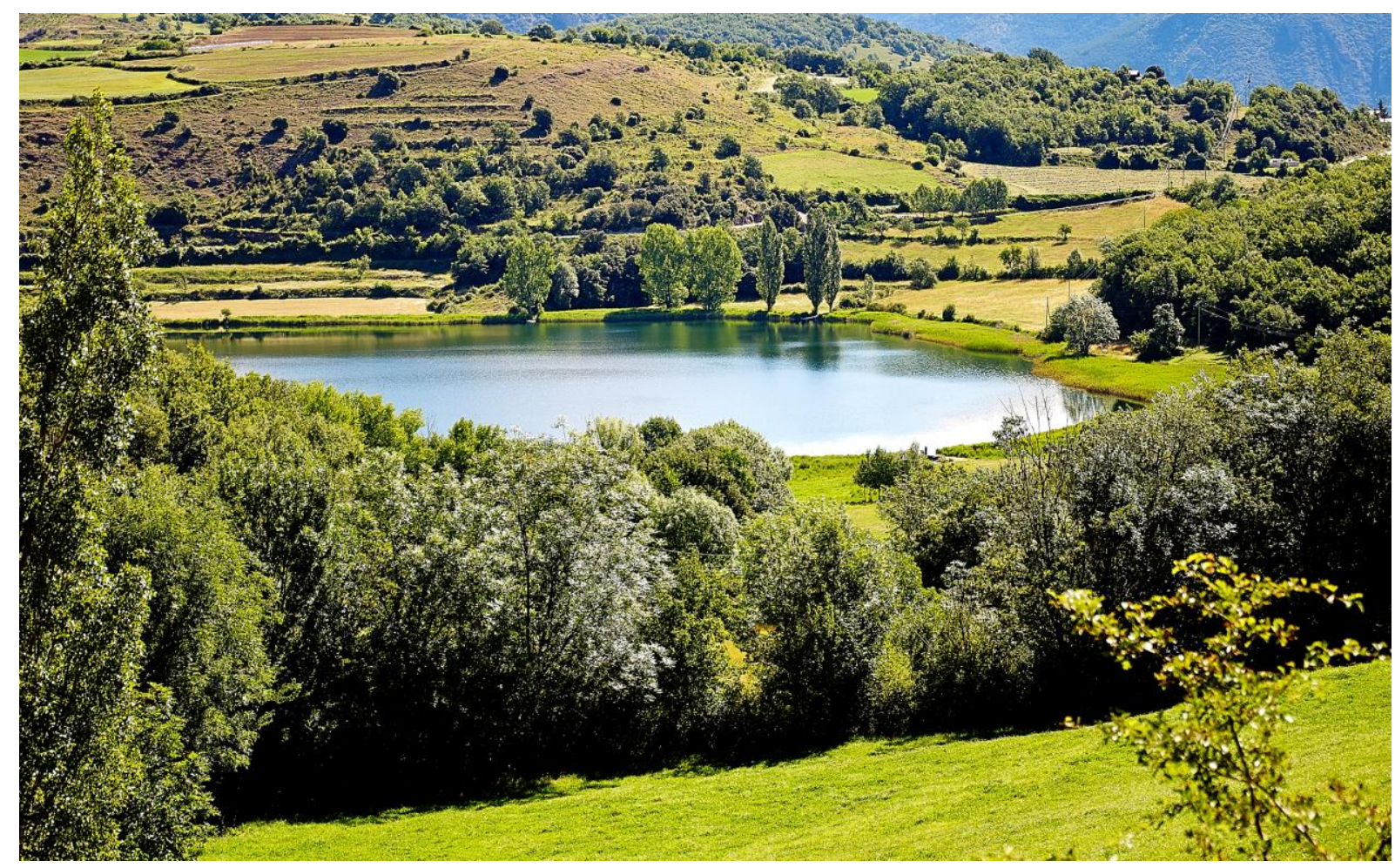

Figure 1. General view of Lake Montcortès facing south. (Photo V. Rull, 2014). 


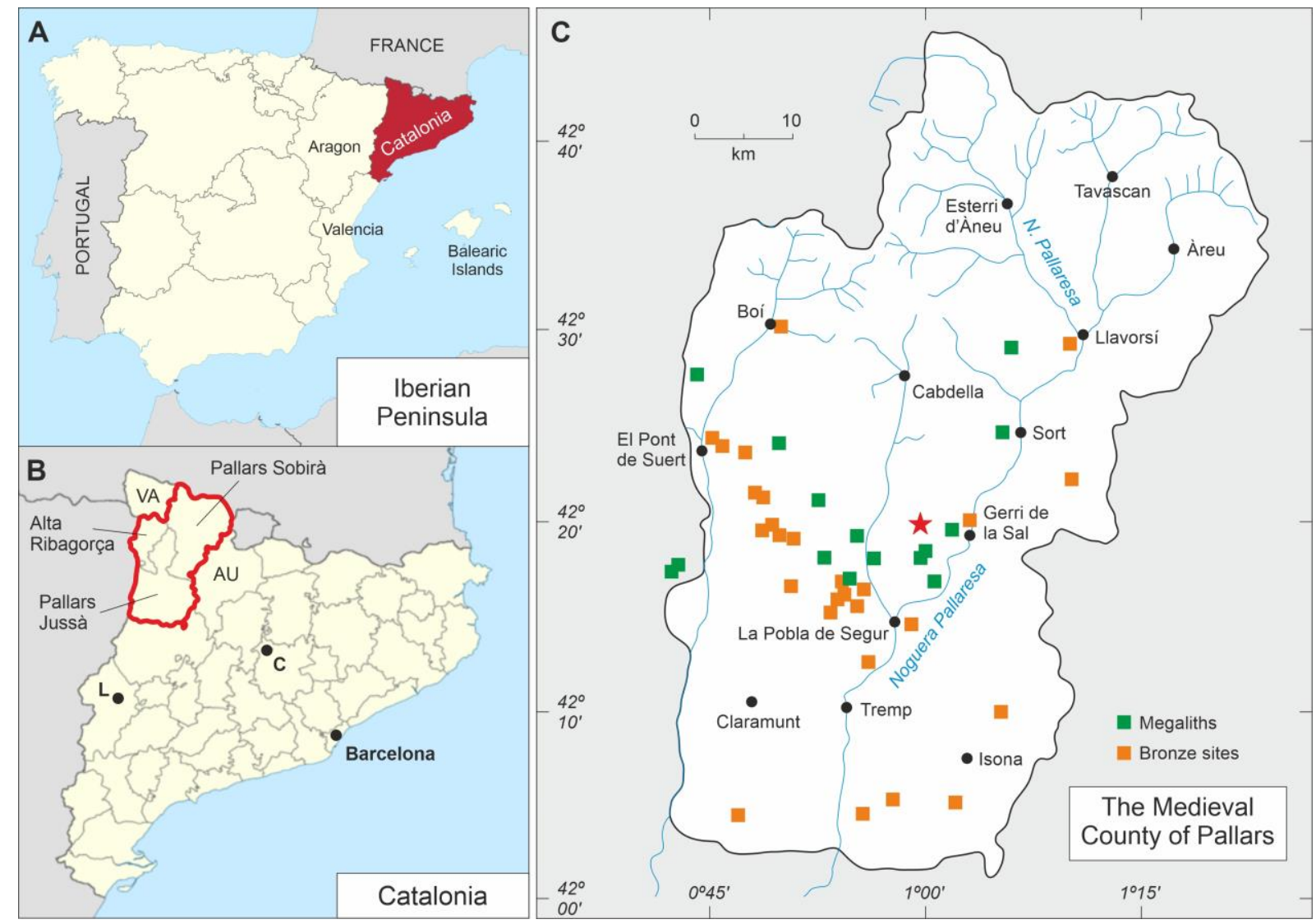

Figure 2. The Pallars region. A) Location of Catalonia (NE Spain) in the Iberian Peninsula. B) Political subdivision of Catalonia. The three comarques that make up the Pallars region are highlighted by the red outline. VA = Val d'Aran, AU = Alt Urgell, C = Cardona, $\mathrm{L}=$ Lleida. C) Medieval Pallars County, with the main present towns and rivers, indicating the megalithic constructions and archaeological sites of the Bronze Age. The location of Lake Montcortès is indicated by a red star. Base maps for A and B were downloaded from Wikipedia. C redrawn and modified from Cots (2005).

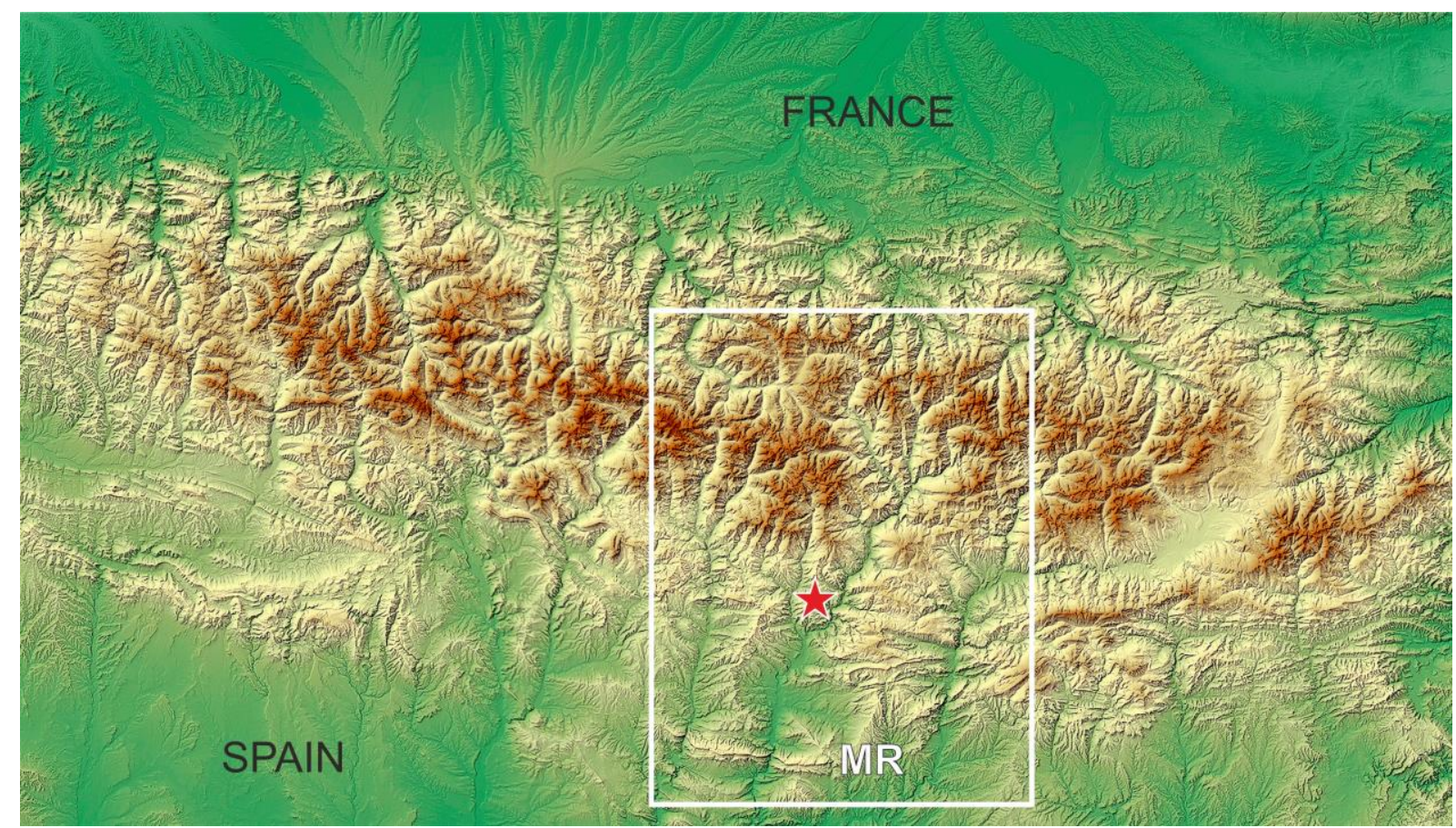

Figure 3. Topographic map of the Pyrenees, the natural boundary between Spain and France, with the location of the Pallars region (white box). The highlands are in orange, medium elevations in yellow and lowlands in green. The location of Lake Montcortès is represented by a red star. MR = Montsec Range. Base map downloaded from Wikipedia. 

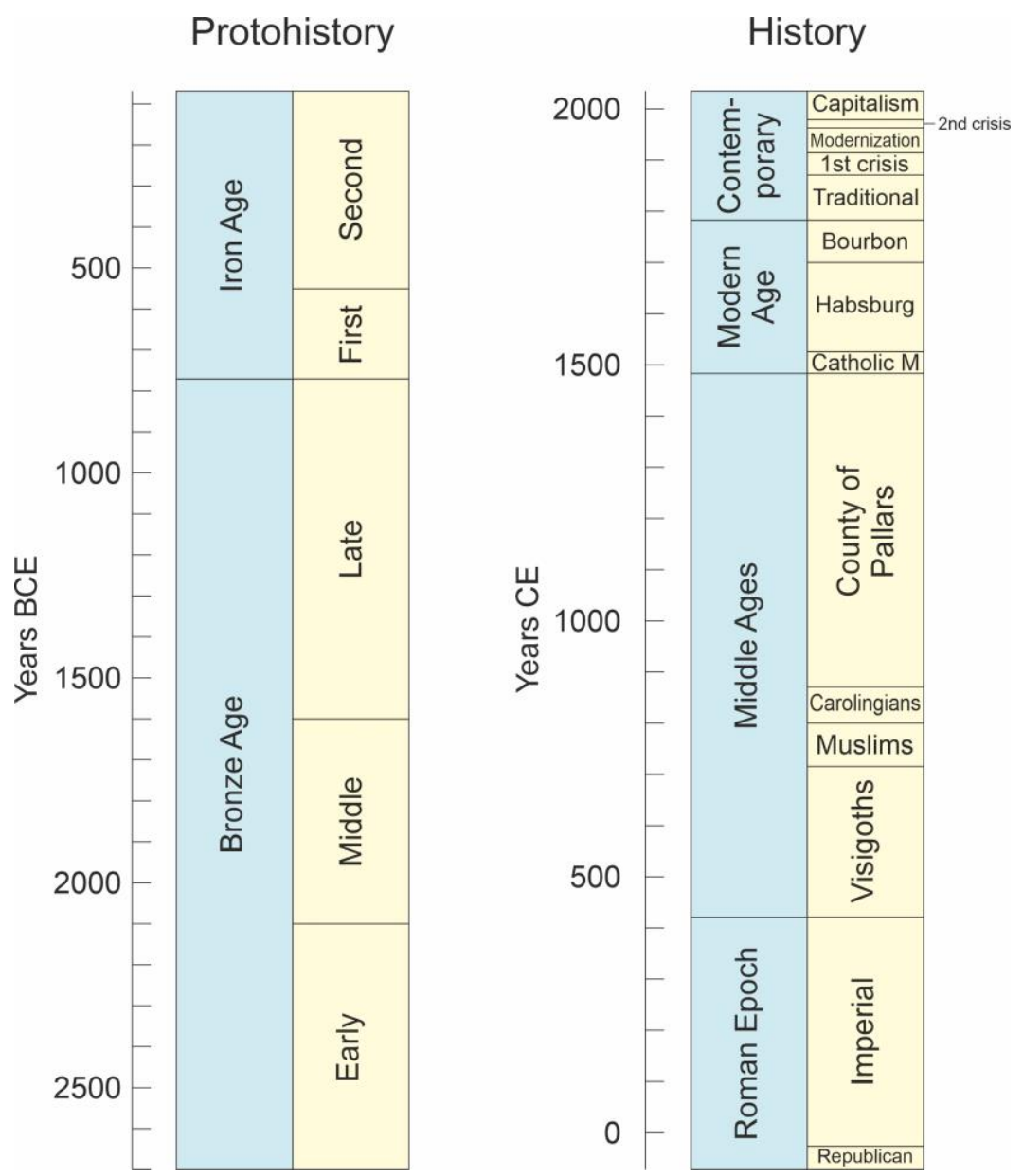

Figure 4. Prehistoric and historic chronology of the Pallars region according to Cots (protohistory and Roman Epoch), Marugan \& Rapalino (2005) (Middle Ages), Bringué (2005) (Modern Age) and Farràs (2005) (Contemporary times). 
THE BRONZE AGE

(2700-800/750 BCE)

The Bronze Age, which followed the Neolithic, was characterized by the development of agricultural practices and polished stone, and its beginning was marked by the inception of metallurgic practices involving the copper-tin alloy (bronze). In the Pallars region, the Bronze Age began at approximately $2700 \mathrm{BCE}(4650 \mathrm{BP})$ and is well represented archaeologically (Fig. 2). This age has been subdivided into three main phases: Bronze Antic (Early Bronze), Bronze Ple (Middle Bronze) and Bronze Final (Late Bronze) (Cots, 2005).

\section{Early Bronze (2700-2100 BCE)}

This phase, also known as the Calcolithic, represented the culmination of the Neolithic Age and was characterized by the appearance of copper and bronze metallurgic and commercial practices. However, stone (quartz, flint), bone and wood were still dominant raw materials for the manufacture of tools, weapons and other objects. Ceramics were also very characteristic, especially because of their novel decorative elements. Human groups were small and scattered, living in caves and outdoor settlements and were organized in consanguineous clans with incipient social differentiation. The main productive activity was nomadic pastoralism in restricted geographical areas. Farming practices were still incipient. Hunting (deer, wild boar) and fishing (trout, eel) were also important activities. The main funerary ritual was burial. It is believed that megalithic practices also appeared during this phase, mainly in the form of dolmens and other types of collective burials, which are also scattered across the region (Fig. 2).

\section{Middle Bronze (2100-1650 BCE)}

The phase was characterized by the significant change that occurred after the mixing of the autochthonous Neolithic population with small groups coming from the north (now France), which crossed the Pyrenees using river passages. This encounter led not only to a different material culture, as noted in the ceramic style, but also to a new ethnic structure of human populations, as noted in the admixture of brachycephalic and dolichocephalic cranial morphologies. Bronze was the main raw material, but stone tools did not disappear, rather they underwent a significant decline and subsisted mainly to support metallurgic activities (sharpeners, melting pots, molds). The most common bronze tools were axes, daggers, arrowheads, spear points, a variety of ornaments and fishing hooks. The development of the bronze industry required commercial reinforcement practices on both sides of the Pyrenees to obtain the necessary products and raw materials. Therefore, contact across the Pyrenees increased, and it is possible that other products, such as flint, salt, pearls and shells, as well as livestock herds, were involved. The nomadic lifestyle persisted, and the caves and outdoor settlements were possibly occupied seasonally. The funerary practices (collective burials) also persisted, but the first individual burials appeared during this phase in the form of stone cists.

\section{Late Bronze (1650-800/750 BCE)}

This phase was characterized by the maximum production and distribution of bronze objects and the decline of megalithic constructions. Additionally the shift in funerary rituals from burial to cremation/incineration was significant, followed by the burial of remains in individual pots or urns. The cemeteries consisted of assemblies of vessels containing ashes, and for this reason, the civilization using this ritual by 1200 BCE has been named Camps d'Urnes (Urn Fields). Some authors believe that the Camps d'Urnes of the Pallars region are very similar to those situated in the southern lowland meadows and have suggested the existence of a single cultural group with nomadic pastoral practices between the lowlands (winter) and the mountains (summer). During this phase, ceramic, predominantly black, was significantly improved in quality and refinement. The bronze metallurgy was similar to that of the Middle Bronze, but the amount and variety of ornamental objects significantly 
increased. A common practice was to accumulate metallic objects in hidden deposits far from human settlements. This has been interpreted as a strategy to protect one's own fortune from eventual traders or people dedicated to melting and reutilizing metals, a common practice by that time. Human settlements were still similar to the former Bronze phases, with most caves and outdoor sites situated along the course of the main rivers. Although population groups were small and had little contact among them, it seems that northern trans-Pyrenean inputs continued during this phase, as deduced from some Indo-European features (e.g., the Camps d'Urnes). Some authors believe that a more or less unified ethnic population existed on both sides of the central Pyrenees during the Late Bronze. The main subsistence activities were pastoralism, farming, hunting and gathering. Pastoralism became rather extensive and possibly transhumant for the first time in a vertical (elevational) sense.

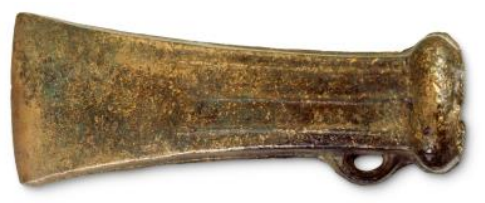




\section{THE IRON AGE}

(800/750-72 BCE)

This is a difficult phase to subdivide chronologically in the Pallars region and in the Pyrenees, in general. Therefore, the central European Alpine chronology has been adopted, and two main phases have been differentiated, namely, the First Iron Age, which coincides with the Hallstat culture, and the Second Iron Age, which corresponds to the La Tène culture (Cots, 2005).

\section{First Iron Age (800/750-450 BCE)}

This phase was the continuation of the Late Bronze culture but with a gradual increase in the importance of iron. However, iron metallurgy was important until the end of this period. The culture of the Camps d'Urnes, also a late Bronze feature, reached its maximum development. According to the first written documents, there was an apparent disconnection between the Pallars region and the southern lowlands, which may suggest that the end of the vertical transhumance developed during the Late Bronze Age.

\section{Second Iron Age (450-72 BCE)}

This was the time of maximum development of the iron industry, which required more complex techniques than the production of bronze. The ore should be submitted to temperatures of $2000^{\circ} \mathrm{C}$ to melt the iron, which necessitates large amounts of charcoal and adequate ventilation to facilitate combustion. This process involved a variety of jobs, which led to more specialization and social diversification, which ended in the appearance of a hierarchical organization of society. This fact is manifest in the funerary rituals, as the most important persons were buried or incinerated in monumental mounds, whereas the rest of the people were grouped together in extensive necropolises. Horses, which were traditionally used as draft animals, began to become riding horses, and the first knights appeared. Only in places with a complicated orography was the penetration of alien influences restricted, and Late Bronze cultures still prevailed. For this reason, some characteristic developments of Iberian culture, such as demographic growth and the construction of fortified cities, did not occur in the Pallars region, except in the south, where lowlands are more accessible. It has been suggested that pastoral activities continued to be an important economic activity and that pastures were exploited and managed collectively, but the evidence is still scarce for a sound assessment. Some information on Pallars protohistoric culture has been obtained from documents written by Roman conquerors. According to them, the Iberian cultures that populated the region were arenosis and andosins in the northern highlands and ilergetes in the southern lowlands. Therefore, just before the Roman conquest, the ethnic groups seemed to have been more diverse than they were in the Bronze Age.

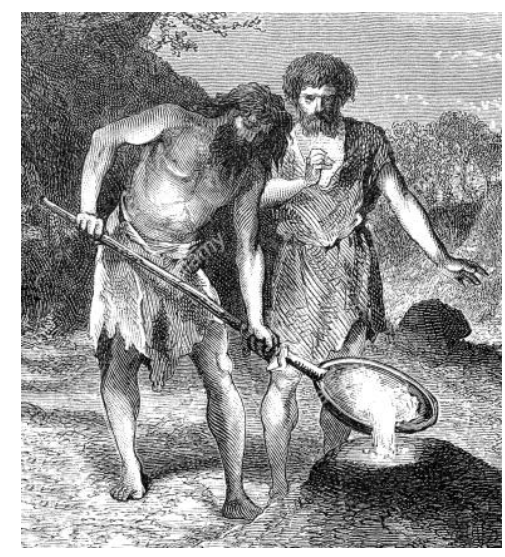




\section{THE ROMAN EPOCH}

\section{(72 BCE-418 CE)}

The Roman incursion into the Pallars region progressed mainly from the south. The first relevant event of the Roman colonization of the Pallars was the foundation of the city of Aeso, presently Isona (Fig. 2 ), by 72 BCE. The existence of another early Roman settlement to the west, called Orretum, which was near the present town of El Pont de Suert, has also been suggested. The frequent hostilities between the northern (Gallia) and southern (Hispania) Roman factions culminated in the foundation of the city of Lugdunum Conventarum (72-69 BCE), the present French town of Saint Bertrand de Comminges, situated only $20 \mathrm{~km}$ north of the present Spain-France border, which may represent the origin of the concept of the Pyrennes as a political boundary. Interestingly, Roman culture was more important in the Aran region, the present Catalan comarca of Val d'Aran (Fig. 2), than in the Pallars region, which has been attributed to the strong orographic isolation of the Pallars and the endurance of its Iberian cultural and socioeconomic patterns. In general, it has been considered that the Roman presence in the Pallars region was somewhat marginal. However, the recent findings of vestiges of some potential Roman villae (cities) in several places near Isona, Sort and El Pont de Suert (Fig. 2) suggest that more archaeological studies are needed for a more informed view. Numismatic evidence suggests that the marginality of the Pallars region was greater during the Roman Republic (up to 27 $\mathrm{BCE}$ ) than during the imperial epoch (Fig. 4). Three main aspects of Roman culture have been highlighted in the Pallars region (Cots, 2005):

\section{Commercial activities}

During the Roman period, the main commercial products were salt, wine, oil, wood, minerals and marble. Salt was needed for human nutrition and, perhaps even more importantly, for raising livestock. The better known salt flats of the region are those of Gerri de la Sal (Fig. 2), but there is no evidence of their utilization during the Roman epoch. The same is true for wine and oil, which should be imported, likely from the southern lowlands. Exportation goods included wood, minerals and marble, as well as other products derived from raising livestock. This merchandise was usually transported by mules that were able to cross high-mountain passages, or by carriages, in the case of flatter lands. Other important transportation paths were rivers, where materials such as wood or marble were possibly carried by rafts, as occurred on the northern Pyrenean side. During Pax Romana, an approximately 200-year period (27 BCE to $180 \mathrm{CE}$ ) of the Roman Empire characterized by general stability, order and prosperity, the Aran region may have been the main Pyrenean connection between the Pallars region and the northern territories, thus facilitating commercial activities between the Gallian city of Lugdunum Conventarum and The Hispanian Aeso.

\section{Farming and forest exploitation}

Again, the development of these activities is poorly known due to the marginality of the Pallars region during the Roman Epoch. It has been speculated that most efforts were dedicated to local subsistence, and the main cultivation system would have been based on biannual rotation-one year planted and one year fallow-as occurred in other regions. Fruit growth prospered at the bottom of the valleys, with emphasis on chestnut and walnut trees, which were introduced by the Romans. Orchards and gardens were probably a minority, with products such as onions, garlic, leek, and probably flax and hemp. Likely, field laborers were carried out with the aid of domestic animals, similar to former times. Forests were exploited mainly for wood, charcoal, hunting and gathering. Wood was used for construction and the elaboration of a diversity of tools, as well as for cooking and heating houses. Charcoal was mostly used in public and private thermae. Beyond wood extraction and fruit gathering, forests were useful for bark harvesting, especially from oaks, chestnuts and pines (useful for leather tanning), and for obtaining forage for livestock. Honey and wax harvesting from wild beehives were also frequent. The first hunting reserves were established for the amusement of the Roman 
aristocracy, as well as for obtaining meat and leather. Frequent prey were bears, wolves, deer, wild cats, sables and otters. The main hunting tools were spears, arrows and nets.

\section{Mining}

The research and exploitation of mineral resources were especially favored during Roman domination. The main products were iron, copper, lead, gold and silver. Mining activities were usually developed by familiar or neighborhood groups, but the property rights of the mines belonged to the Empire. The people who exploited the ores obtained the benefits needed to cover the lease, extraction and transformation costs. The deposits were small and close to the habitation sites, and the transformation industry was also a local practice, but the general economy and the commercialization of the products were strictly controlled by the central Roman administration.

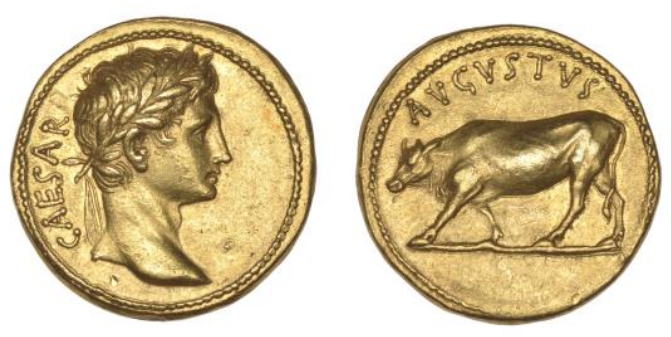




\section{THE MIDDLE AGES}

\section{(418-1488 CE)}

In general, the Middle Ages is a period of more than 1000 years between the fall of the Occidental Roman Empire (476 CE) and the conquest of Constantinople by the Turks (1453 CE), which implied the disappearance of the Oriental Roman Empire. In the Pallars region, the initial date of the Middle Ages is considered to be $418 \mathrm{BC}$, when the Visigoths settled at the nearby French city of Toulouse (Tolosa, at the time) (Fig. 5), whereas the end has been situated in $1488 \mathrm{CE}$, coinciding with the end of the County of Pallars. Chronologically, the Middle Ages in the Pallars have been subdivided into four main phases, namely, Visigothic domination, the Muslim phase, Carolingian occupation and the County of Pallars (Marugan \& Oliver, 2005) (Fig. 5). These phases are briefly described below, and then the main social and land-use features of the Medieval Pallars are described to finalize with the extended crisis that immersed the Pallars region up to the Modern Age.

\section{Chronology}

The Visigothic domination (418-711 CE)

The end of the Occidental Roman Empire occurred when the Barbarian cultures occupied its lands. In southern Gallia, the Visigoths consolidated their dominion with the foundation of the reign of Tolosa in the region of Septimania ( $418 \mathrm{CE}$ ). Tolosa was conquered by the Franks in $507 \mathrm{CE}$, and the Visigoths were forced to advance toward the Iberian Peninsula, where they founded the Kingdom of Toledo and remained there until the Muslim invasion, in $711 \mathrm{CE}$. The presence of the Visigoths in the Pallars region is poorly documented historically and has been considered a dark period before the establishment of the feudal system. Archaeological and paleobotanical evidence has provided some clues to infer the main features of this period. The disarticulation of the Roman world led to significant changes in the exploitation of natural resources, mainly in montane environments, where Roman domination had been much less intense than in the lowlands. The disappearance of the Roman Empire led to the reinforcement of local autochthonous societies and the development of new farming, mining and livestock raising strategies.

\section{The Muslim phase (711-800 CE)}

The Muslim Empire dominated most of the Iberian Peninsula, which they called Al-Andalus, and arrived at the Pyrenees from the south. There is little information about the Muslim influence on the Pallars region and the Pyrenees, in general, but it is believed that no significant socioeconomic changes occurred compared to earlier times. The Pallars region was part of the northern boundary of AlAndalus and was populated by a diversity of cultures. This was a relatively short phase (less than a century) that ended with the conquest of the Pallars by the Carolingians.

The Carolingian occupation (800-872)

On behalf of the Carolingian Empire, funded by Charlemagne, the counts of Tolosa conquered the Pallars in 800 CE to incorporate this region into the so-called Marca Hispanica (Hispanic Marches), a buffer territory created to serve as protection against possible Muslim invasions from the south (Fig. 5). In this way, the Pallars was incorporated into the Frank Empire, and the Counts of Tolosa controlled a vast territory that spanned both sides of the Pyrenees. After a turbulent epoch with frequent replacements in the political control of the Pallars, Count Ramon II culminated in the process of the separation from Tolosa and the creation of the independent County of Pallars. 


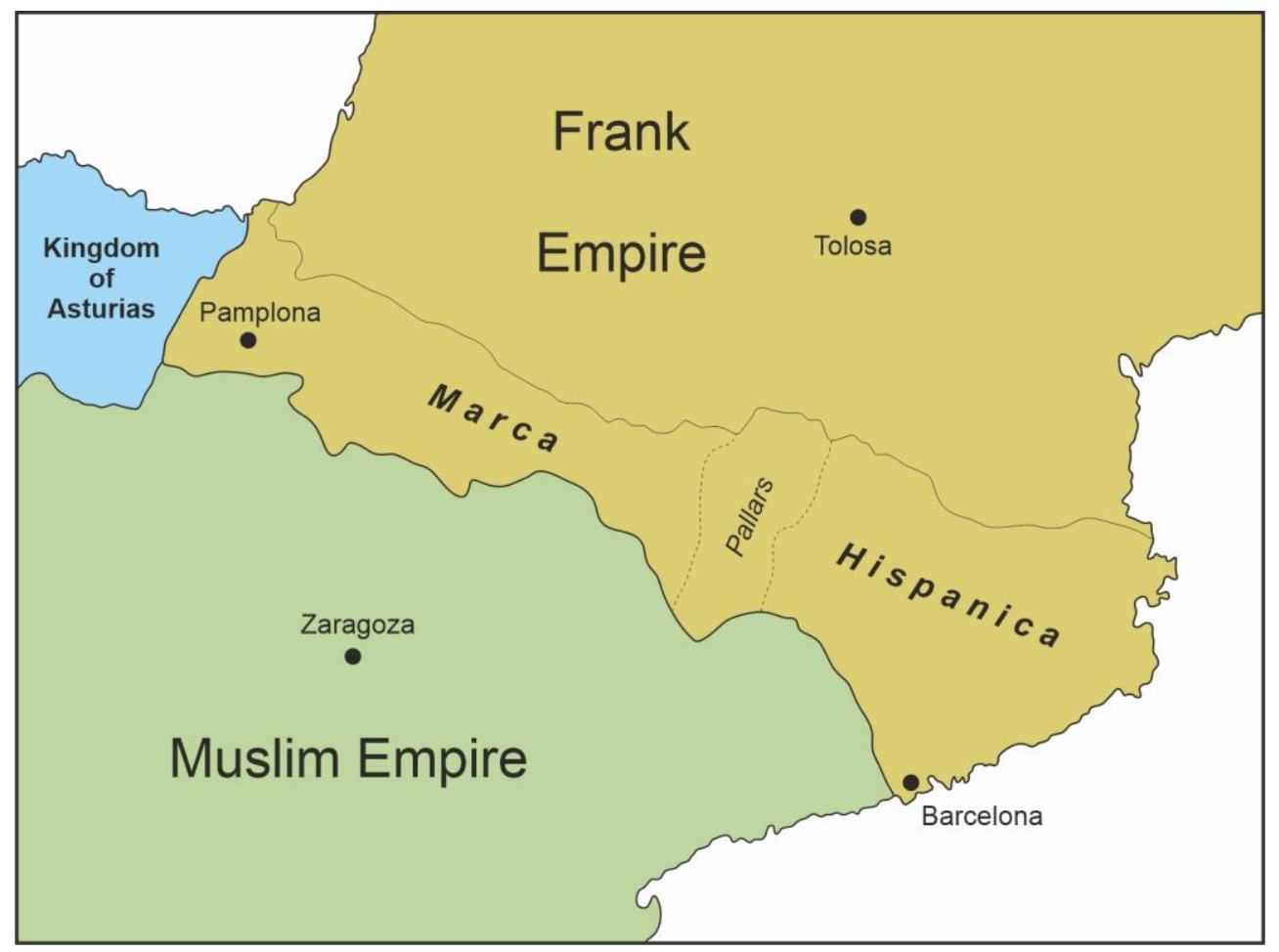

Figure 5. The contact zone between Frank and the Muslim empires in the $9^{\text {th }}$ century, after the establishment of Marca Hispanica by the Carolingians. Redrawn and modified from Marín (1995).

\section{The County of Pallars (872-1488)}

This was the longest phase (more than six centuries) of the Medieval Pallars, ranging from the independence of the county from the Frank Empire to its conquest by the Catalan-Aragonese crown (formed by the dynastic union of the Kingdom of Aragon and the Principality of Catalonia) in the $15^{\text {th }}$ century. In the beginning, the Frank counts of Tolosa still maintained some privileges on the political affairs of the County of Pallars, which was also submitted to violent assaults from the southern Muslim Empire, especially by the factions settled in Zaragoza (Fig. 5). The Pallars did not consolidate its full independence until the death of Count Ramon II in 920. However, the independence of the county was paralleled by a territorial splitting among the descendants of Ramon II, a practice that continued for some generations, until the early $11^{\text {th }}$ century, when Pallars County was subdivided into two counties (Jussà and Sobirà) (Fig. 6), which constituted the geographical basis for the modern concept of the Pallars region. From this point, succession conflicts and the armed clashes were constant between the Jussà and the Sobirà counties, with the participation of the County of Urgell, which roughly coincided with the present-day comarca called Alt Urgell, situated to the east of the Pallars region (Fig. 2). It should also be stressed that most of these disputes for political power and territorial expansion took place under the feudal system (see below) and were largely prompted by the interest in obtaining as much rent as possible. By the end of the $11^{\text {th }}$ century, an internal agreement was reached, and some disputed territories were left under a regime of shared rights between the Jussà and Sobirà counts, although the southeastern area was still disputed with the County of Urgell (Fig. 6).

The County of Pallars did not disappear but was significantly reduced when, due to the lack of successors, the territory of Jussà was sold to the Catalan-Aragonese crown and incorporated into this kingdom. By the time the Catalan-Aragonese crown was led by Jaume I (1208-1276) and dominated most of the eastern part of the Iberian Peninsula, roughly coinciding with the present regions of Catalonia, Aragon and Valencia, with the addition of the Balearic Islands (Fig. 2), after expelling the Muslims, which became restricted to the Granada region, in the southeastern Iberian coin (Fig. 7). 


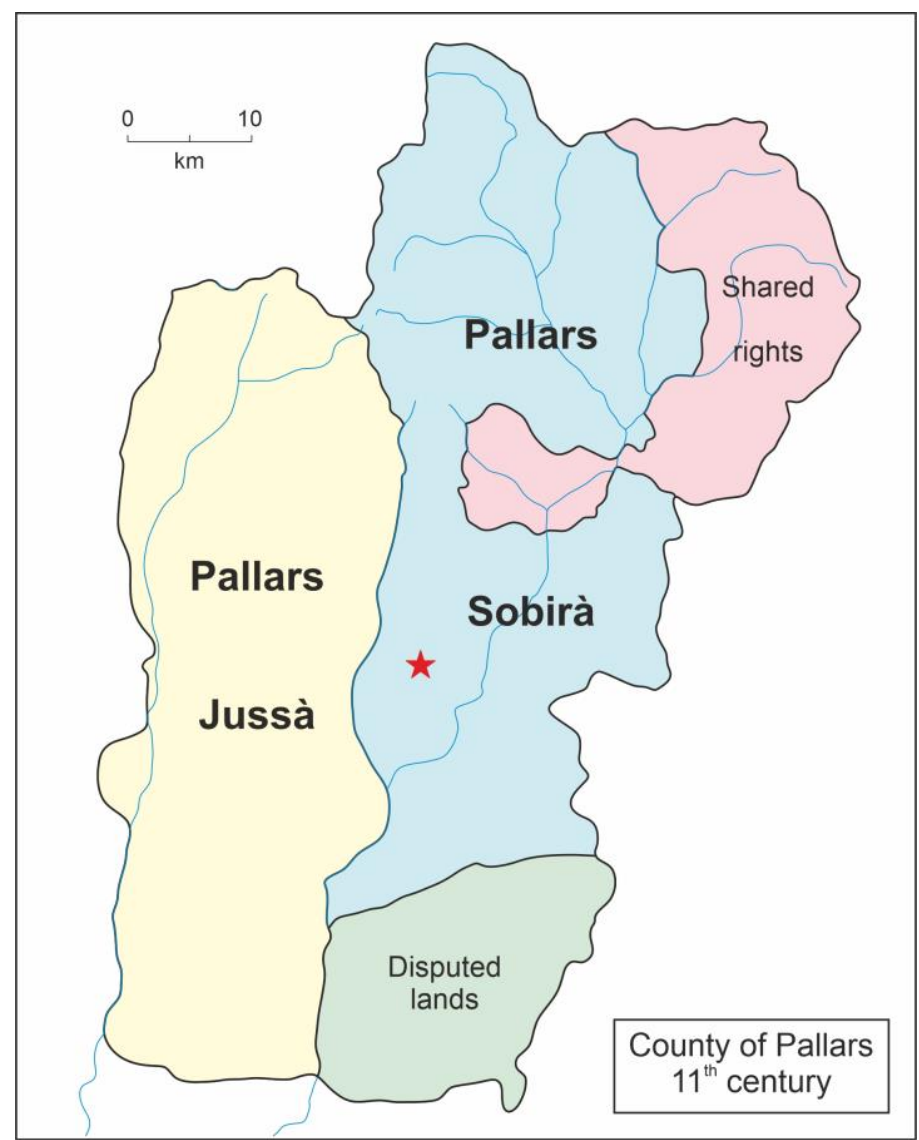

Figure 6. Territorial subdivision of the County of Pallars in the $11^{\text {th }}$ century. The red star indicates the location of Lake Montcortès. Redrawn and modified from Marugan \& Rapalino (2005).

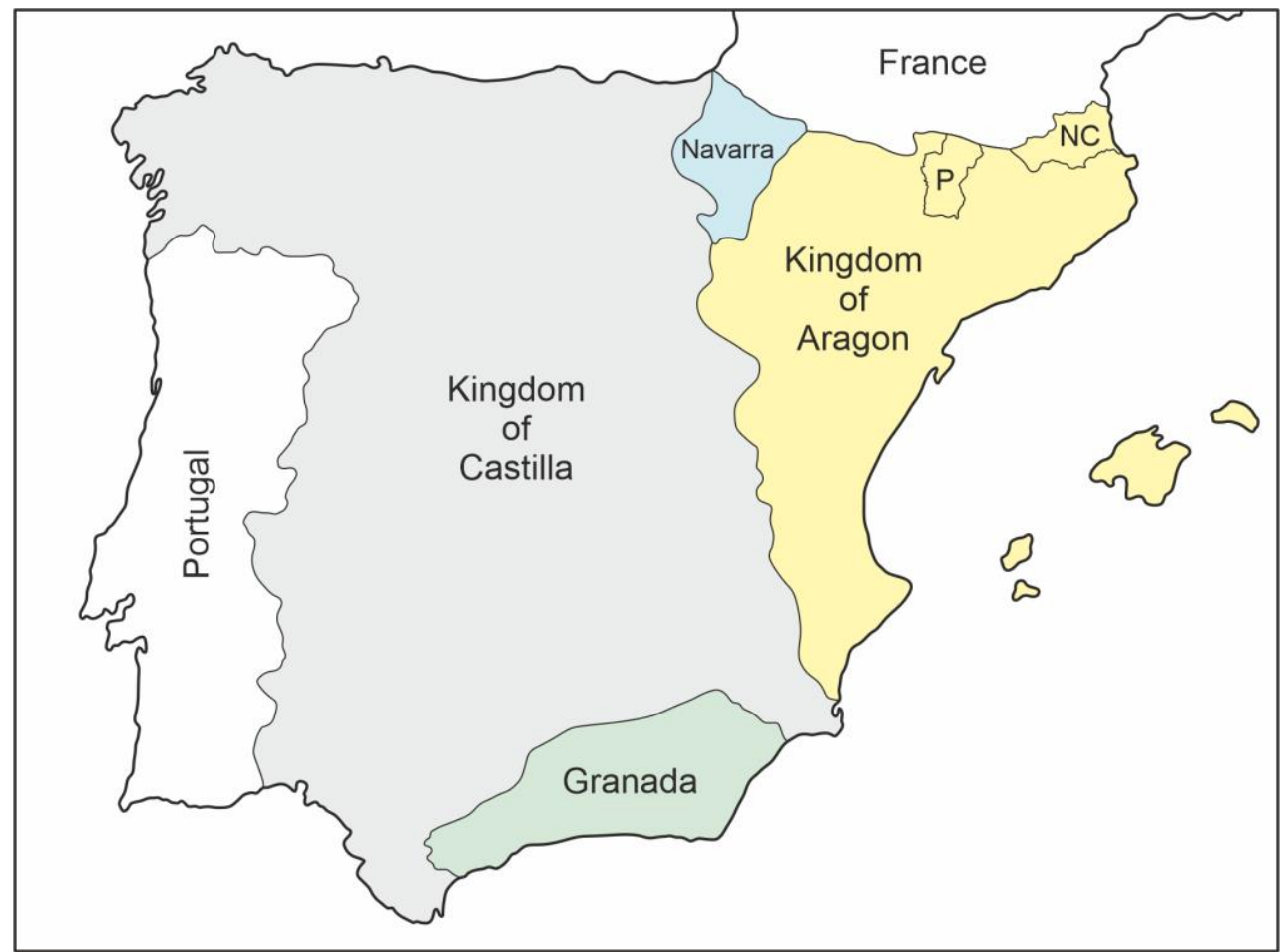

Figure 7. Sketch map of the Iberian Peninsula and its political subdivisions at the end of the Middle Ages. $P=$ Medieval Pallars region, NC = Northern Catalonia. Redrawn and modified from Marín (1995). 
From this point onward, only the County of Pallars Sobirà remained. However, this county also experienced problems, in this case of an economic nature, and was sold in 1236 to the House of Comenge from the northern side of the Pyrenees, a situation that lasted until 1294. In this case, however, Pallars Sobirà maintained its political independence as a county, despite the increasing interventionism of the Catalan-Aragonese crown. From 1295 to 1488, the Pallars was dominated by the Catalan House of Mataplana and suffered repeated assaults from the Gascons, also from the north of the Pyrenees, which prompted the invasion of the Pallars by the Aragonese King Jaume II. The relationships between this kingdom and the Pallars aristocrats, who defended its independence, were difficult and led to more wars and conflicts, culminating in a revolt against the Aragonese King Fernando I, in 1462. The last count of Pallars, Hug Roger III, continued to fight with the crown, but he was defeated and sentenced to life imprisonment. In 1488, the County of Pallars was conquered by the Aragonese King Fernando II, on behalf of the newly created Castilla-Aragon crown, and upgraded the county to a marquisate, under the lead of the dukes of Cardona (Fig. 2), who also became the marquises of Pallars.

\section{Territory and society}

The feudal system initiated its development in the $9^{\text {th }}$ century during the Carolingian occupation and was consolidated in the $11^{\text {th }}$ century during the governance of the counts of Pallars. This system was based on the geographical subdivision of the territory according to the natural valleys and their political grouping according to the counties, in the first place, and then around the castles of the nobility and the parishes of the Catholic church. This section summarizes these points and briefly explains the social composition of the Pallars during the feudal epoch.

\section{The Pyrenean valleys}

The first mentions of Pallars County date from the mid- $9^{\text {th }}$ century. In the beginning, the term "Pallars" referred to a specific district, possibly an ancient Roman or Visigothic city (civitas), situated in the middle course of the Noguera Pallaresa River, south of Llavorsí (Fig. 2). Other similar districts existed and were organized geographically into valleys. These initial districts were progressively suppressed due to the expansion of a unique county jurisdiction and the proliferation of castles and parishes, each with their own territories. In this framework, it is believed that the county of Pallars resulted from the expansion of the initial Pallars district mentioned above.

\section{The feudal castles}

The castles and the territories they controlled were fundamental government elements during feudalism. These castles were ruled and administered by nobles through the delegation of functions from the counts of Pallars. As was common in feudal systems, these nobles had civil jurisdiction over the people who lived within their territories and offered protection in exchange for tributes, maintenance and land-use laborers. The first and more fortified castles appeared in the $10^{\text {th }}$ century and were mainly situated to the south, close to the border between the Pallars and the Muslim Empire, and to the west, where the Roman and Visigothic presence had been greater in the past. In the northern highland valleys, where autochthonous organization forms were stronger, feudal control was exerted mainly by the church. The occurrence of frequent successional and territorial disputes in the $11^{\text {th }}$ century also led to the proliferation of castles in the Pallars territory. Another wave of castle construction took place during the $13^{\text {th }}$ and $14^{\text {th }}$ centuries when Pallars Sobirà was frequently invaded by the northern Gascons.

\section{The ecclesiastic organization}

Until Visigothic domination, the Pallars churches were under the jurisdiction of the Catholic diocese of Lleida (Fig. 2), but the conquest of this city by the Muslims broke this relationship. When the counts of 
Tolosa conquered the Pallars, in $800 \mathrm{CE}$, this region became part of the diocese of Urgell, a situation that remained during the rest of the Medieval period. During the $9^{\text {th }}$ and $10^{\text {th }}$ centuries, many monasteries were founded in the Pallars region, which has been recognized as one of the main centers of the development of monastic life in Catalonia. Many of these monasteries, however, experienced a further decline and disappeared or became integrated into the domains of other monasteries. Only the monastery of Santa Maria de Gerri (Fig. 8) - situated near the present village of Gerri de la Sal (Fig. 2 ), less than six $\mathrm{km}$ east of Lake Montcortès-remained and acquired a predominant role in the development of the Medieval Pallars. The heritage of this monastery quickly increased thanks to the donations of the counts and other relevant nobles, as well as the absorption of other smaller surrounding monasteries and their possessions. Collaboration between religious and political power was common during the Middle Ages and was manifested in the origin of so-called parishes (parròquies), with ecclesiastic, administrative and military responsibilities, as well as in the increasing participation of the diocese or Urgell in county affairs.

\section{The social composition}

In the feudal system, the feudal lord was the owner of the land included in his dominium and of the people who worked it (rustici), who paid a rent for living and working there. This payment required production surpluses to guarantee not only the survival of the rustici but also the maintenance of the feudal lords and to cover the cost of transport, storage and commercialization of the final products. The nobility was a minority of privileged people dedicated mainly to war or an ecclesiastic career. The higher nobility class was formed by the magnates, who possessed considerable patrimonies and were closer to the counts. The second class was composed of castlans, who owned a single castle, whereas the third class, the minor nobles, was usually knights at the service of the counts or the church. The majority of the population consisted of families of farmers ruling their own lands (alous), grouped in small villages, frequently with common goods, which were administered collectively. From the $10^{\text {th }}$ century onward, the alous were progressively degraded and transformed into part of the large properties of laic and ecclesiastic nobility. However, some of the peasant properties resisted the feudal impetus and subsisted locally.

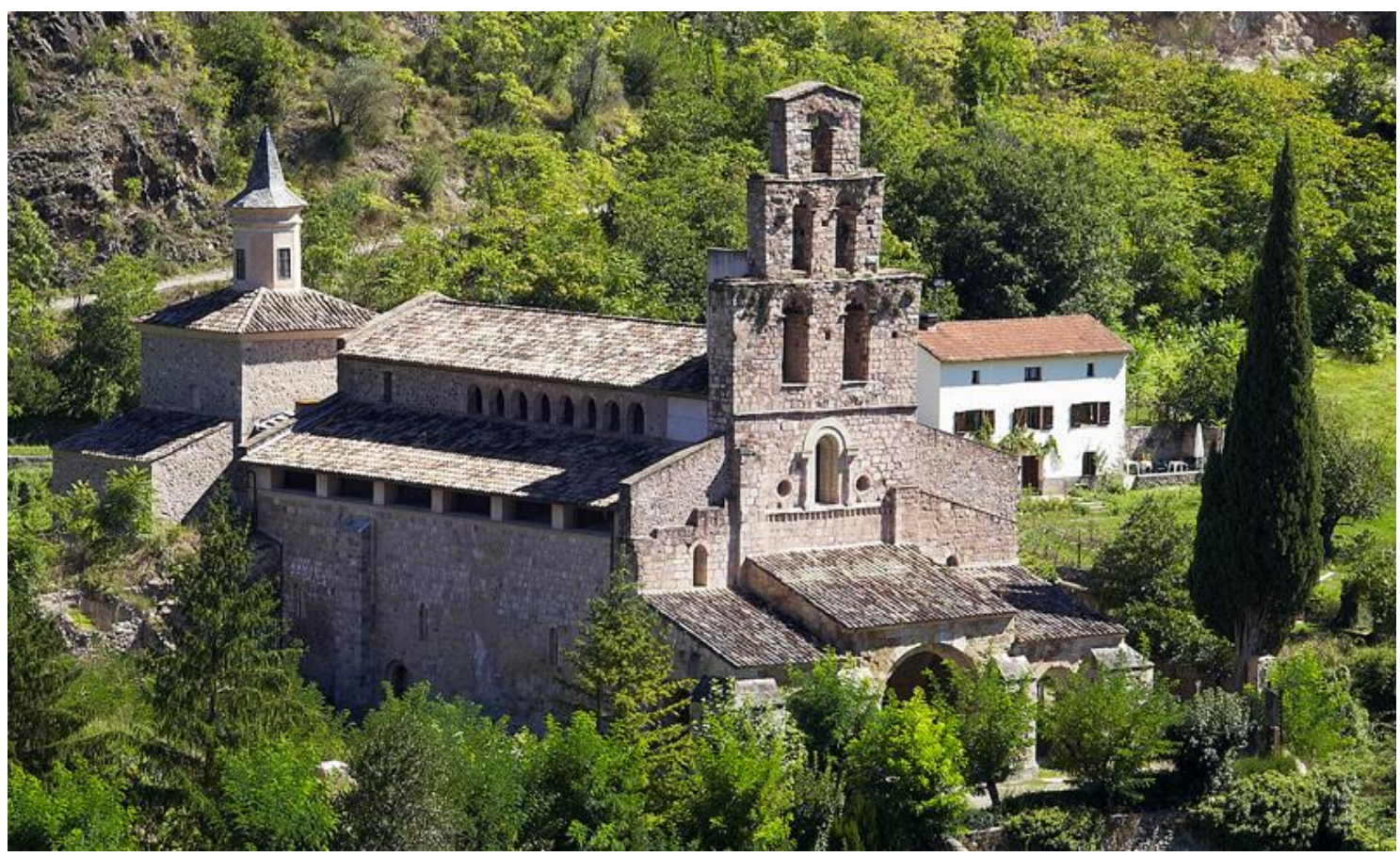

Figure 8. Remains of the monastery of Santa Maria de Gerri, founded in 809. Today, only the Romanesque temple built in the $12^{\text {th }}$ century is preserved (Photo V. Rull, 2014). 


\section{The feudal landscapes}

\section{Settlement and land use}

The Medieval Pallars was fundamentally rural, without important cities, with two main welldifferentiated sectors: the zones of habitation and the working areas, with their corresponding communication pathways. The villages were often developed around or close to churches. There were many isolated houses with associated terrains (masos). There were also cave dwellings, mainly in the southern Pallars, where climatic conditions were more suitable for this type of occupancy. The working lands were preferably crop fields, meadows and pastures, which were easier to control by the feudal system in terms of rent collection than other less stable terrains such as wetlands, river margins or forests. The itinerant slash-and-burn agriculture was practiced mainly in the montane areas, where it provided a diversity of land uses in a small area and was adapted to the enhanced seasonality of these environments. However, these practices disappeared with the consolidation of the feudal system (between the $9^{\text {th }}$ and $11^{\text {th }}$ centuries), which required strict control of the people who worked the land and where and how much they produced, to properly establish and receive rent payments. Therefore, the introduction of the feudal system represented the end of the ancient small-scale subsistence economy and the beginning of more stable and extensive land use.

The main crops were cereals, olive and vine, which have been considered the three more traditional Mediterranean crops. The first cereal mills appeared in the $9^{\text {th }}$ and $10^{\text {th }}$ centuries and used hydraulic power. This activity was also monopolized by the feudal lords, who received rents for the right of use of the mills. The nutrient depletion produced by intensive cereal cultivation was compensated by a system of crop rotation using legumes. The use of manure of animal origin was not documented until the $12^{\text {th }}$ century and was possibly restricted to barley crops, which were the most demanding. Extensive olive tree cultivation has been documented in the Pallars since the $11^{\text {th }}$ century, especially in the southern lowlands, where the climate is more appropriate for this tree, whose northern boundary seems to have been situated near Montardit, approximately $10 \mathrm{~km}$ northeast of Lake Montcortès. This activity was also a feudal initiative, as the cultivation of olive is rather demanding in terms of working time, supporting facilities and commercialization. The introduction of vine cultivation in the Pallars region has been considered the continuation of a Roman tradition, possibly favored by mid-Medieval climatic warming. The first vineyards were documented in the $9^{\text {th }}$ century around the first churches and monasteries as marginal crops for local consumption. After feudal consolidation, in the $11^{\text {th }}$ century, the vineyards became more extensive, and viticulture was a programmed crop subjected to rent payments, which reached montane areas at elevations above $1000 \mathrm{~m}$.

\section{Pastures}

One of the main innovations of the Middle Ages was the development of herding practices involving long-distance or horizontal transhumance. As noted above, vertical transhumance was practiced from antiquity (possibly the Bronze Age) and was the main type of livestock movement performed until the $9^{\text {th }}$ century in the Pallars region. Vertical transhumance implied the seasonal short-distance migration of livestock herds (mainly sheep flocks) and the people responsible for them between summer (highlands) and winter (lower valleys) pastures and was mainly performed on mountain regions by small landowners. In contrast, horizontal transhumance involved the long-distance displacement of livestock across large regions, which required a different social organization and a more specialized herding system. The monasteries were the first to develop long-distance transhumance, and other laic feudal owners incorporated this practice in the $10^{\text {th }}$ century. However, smaller individual owners (masos) did not disappear, thus contributing to a diversity of pastoralism and transhumant practices. Horizontal transhumance involved large herds that were obtained, in part, from the rents of individual owners in the form of living animals. Frequent conflicts between and within ecclesiastic and laic owners for the use of pastures have been extensively documented between the $11^{\text {th }}$ century and the rest of the Medieval period. In contrast, there is a significant lack of documentation on the location and 
extension of pastures and other facilities related to this activity (water and salt sources, temporary corrals, shepherd huts), which hinders drawing conclusions about the relevant economic aspects, such as the existence or absence of overgrazing.

\section{Mineral resources}

Salt is an important component of the animal diet as a source of sodium and chlorine. This resource was especially necessary for the development of large sheep flocks and horizontal transhumance, and as seen in other fundamental needs, salt extraction and commercialization were also monopolized by feudal lords from the $9^{\text {th }}$ to the $15^{\text {th }}$ centuries. Regarding metals, the Visigoths inherited the Roman mining practices and expanded these activities to marginal zones that had been previously considered economically worthless by the Roman Empire. At the same time, the production of precious metals was restricted for the benefit of the iron industry to meet the local needs for weapons and farming tools. This situation lasted until the $9^{\text {th }}$ century, when laic and ecclesiastic feudal landowners took control of iron production and commercialization. This contributed to the expansion of agriculture and the weapon industry, and the blacksmith trade reached great prominence, as did those of tanners and shoemakers. This relevance required more feudal control, and the first smithies and forges were preferably located in watercourses (the forges used hydraulic power) near the castles and monasteries.

\section{The late Medieval crisis}

At the end of the Medieval period (between 1350 and $1487 \mathrm{CE}$ ), during the government of the houses of Comerge and Mataplana, the Pallars region underwent a significant depopulation by the emigration of people to major urban nuclei. This led to a general impoverishment and a deep territorial restructuration characterized by a permanent struggle for the occupancy of abandoned crops, pastures and forests. The depopulation occurred in two phases. The first phase began in the late $13^{\text {th }}$ century and was fostered by the Gascon invasions and the further inception of the black plague (1348 CE). The second depopulation phase was linked to the increasing intensity of wars between the Pallars counts and the Calatan-Aragonese crown (the Pallars war), which peaked in the late $14^{\text {th }}$ century and ended with the incorporation of the Pallars region into this kingdom. Another factor that could have contributed to the Medieval crisis was the incoming of the Little Ice Age, a phase of cold climate that contrasted with the Medieval warmer climates culminating in the "optimum" that occurred in the $11^{\text {th }}$ century. However, wars and climate change alone cannot fully explain the late Medieval crisis, which was also the result of a general dismantling of the feudal order. For a long time, the traditional explanation of the Medieval crisis has been based on an eventual overpopulation combined with diminishing returns from land exploitation. However, this interpretation does not consider the potential role that a large number of idle people, i.e., laic and ecclesiastic feudal lords, played in the crisis. The existence of an increasing number of unproductive consumers dedicated only to forcing others to work to satisfy their own needs and increase their economic prosperity should be considered an important factor to explain the self-induced feudal collapse.

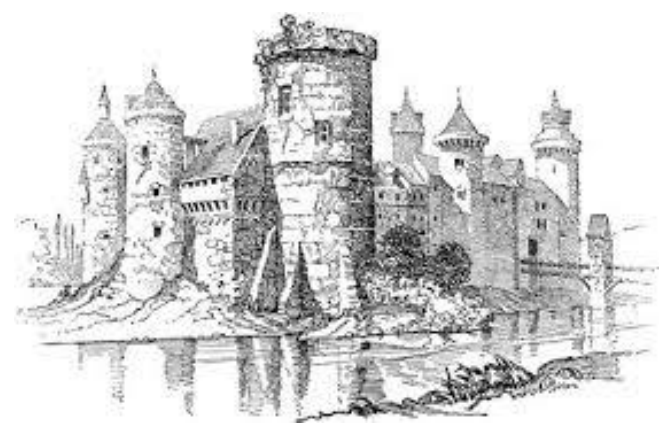




\section{THE MODERN AGE}

\section{(1488-1789 CE)}

In the Pallars region, the Modern Age extended from the end of the Pallars war (1488 CE) to the French Revolution (1789 CE). From a socioeconomic point of view, the Modern Age represented the transition between the feudal regime of the Middle Ages and the precapitalist society that emerged in the late $18^{\text {th }}$ century. Politically, the Pallars region also underwent significant changes that should be introduced for a proper understanding of its socioeconomic development (Box I).

\section{Box I. Political chronology of the Modern Age in Spain}

The Catholic Monarchs (1469-1516 CE). The marriage of Fernando II of Aragon and Isabel I of Castilla, known as the Catholic Monarchs, at the end of the Medieval epoch (1469) determined the union of these kingdoms (Fig. 7). However, the Aragonese kingdom, which included the Principality of Catalonia, experienced few changes in its internal policy, and the nobility retained most of its privileges until the beginning of the $18^{\text {th }}$ century. The political unification of the present Spanish territories, however, did not occur until the conquest of the kingdoms of Granada (1492 CE) and Navarra (1512 CE) by the Castilla-Aragon crown, at the beginning of the Modern Age. The conquest of Granada coincided chronologically with the discovery of America by Colon, a venture that was funded by Catholic Monarchs. After the death of Isabel I (1504 CE), her husband Fernando II governed until $1516 \mathrm{CE}$, and as seen above, was responsible for the conquest of the county of Pallars (1488 CE) and its annexation by the kingdom of Aragon as a marquisate.

The Habsburgh dynasty (1517-1700 CE). The Habsburg or Austrias governed the unified Spanish kingdoms for almost 200 years by dynastic succession, as the first Habsburg king, Charles I, was the grandchild of the Catholic Monarchs. Charles I inherited the dominions of its four grandparents, that is, Castilla, Aragon and the recently occupied American territories, from the Catholic Monarchs; and Austria, the Netherlands and adjacent territories from Maximilan I of Austria and Mary of Borgogne. In this way, Charles I was one of the most important European monarchs of the $16^{\text {th }}$ century, and after the death of his grandfather Maximilian I, in 1519, he was proclaimed Holy German Emperor under the name of Charles V. He abdicated in $1556 \mathrm{CE}$. For the Principality of Catalonia, one of the most relevant events of the Habsburg period was the treatise of the Pyrenees, signed in 1659 by the Spanish king Felipe IV, who reigned between 1621 and 1665 $\mathrm{CE}$, and the French King Louis XIV. This treatise ended the war between Castilla-Aragon and an Anglo-French alliance for several European possessions and deeply affected Catalonia, which lost its northernmost region, known as northern Catalonia (Fig. 7), which became incorporated into France.

War of the Spanish succession (1700-1714 CE). The last Habsburg king of Spain was Carlos II, who died in $1700 \mathrm{CE}$, leaving no descendants. This was the origin of the war for succession between the French Bourbons, represented by Felipe d'Anjou, grandson of Louis XIV, and the Austrian side of the empire, represented by Leopold I. As one more manifestation of the fragility of the Castilla-Aragon unity, Castilla gave its support to the Bourbons, whereas Aragon supported the Austrians. The conflict became international with the involvement of England, Portugal and the Netherlands, which supported Austrians, to prevent French expansionism. The war finished with the treatises of Utrecht and Rastatt (1713-1714 CE), which recognized Felipe d'Anjou as the king of Castilla-Aragon (Felipe V) provided he renounced his successional rights to the French throne. The Austrian side also received some European territories under the dominion of Spain as compensation, which decimated French hegemony and equilibrated European powers. The proclamation of Felipe $V$ signified the end of the Aragon kingdom, whose last redoubt was the Catalan city of Barcelona, which was subdued in 1714 by the Castillian army with the aid of France. During the succession war, most of the Pallars region was invaded by the French army, which reached Tremp (Fig. 2) in 1712.

The Bourbon dynasty (1714-1808 CE). The inception of the Bourbon dynasty signified the end of the institutional peculiarities and the civil rights of Catalonia, which had been maintained by the crown of Aragon until the end of the Habsburg dynasty. The culmination of the new absolutist regime was the so-called Nueva Planta decree (1716 CE), which created Spanish citizenship or nationality with no distinction between Castillian and Aragonese, as in former times. Internal borders and customs were abolished (except in the Basque territory), thus granting the right to all Spaniards to trade with the American colonies (not only Castillians, as previously). Most regional institutions were abolished, and top civil servants were appointed from Madrid, the king's court city. Castillian was declared the sole language of government, and Latin, Catalan and other languages were displaced. These decrees were the origin of the Spanish absolutist monarchy, centered on Castilla, which dominated until the last Bourbon king of the Modern Age, Carlos IV, who governed between 1788 and 1808 CE, when the French occupation began.

Within this political-chronological framework, the thematic sections distinguished by Bringué (2005) for the Modern Age in the Pallars region are territory, population, institutions and economy. A brief account of these aspects is provided below.

\section{Territory}

As noted above, the Pallars war ended with the disappearance of the County of Pallars Sobirà, which was transformed into a marquisate ruled by the house of Cardona, under the dominion of the Aragonese kingdom. It has been estimated that the marquisate comprises approximately $53 \%$ of the present comarca of Pallars Sobirà and $27 \%$ of the present Pallars Jussà (Fig. 2). The marquisate was a 
discontinuous area and shared the ancient territory of the Medieval Pallars region with other royal and noble dominions, including viscounts, baronies, abbeys, lordships and other minor manors (Fig. 9). The northern highlands of the marquisate were known until the $17^{\text {th }}$ century as the Pallars Sobirà, and the southern lowlands were called the Pappars Jussà. Despite this, the Pallars maintained its identity as a single historical region.

\section{Population}

The late Medieval crisis made resulted in the disappearance of one-third of the villages, and the villages that remained were severely reduced. The Modern Age recovery was relatively rapid, as the number of houses increased by a factor of 2.5 during the $16^{\text {th }}$ century (Fig. 10). This increase was due to the creation of new houses by the descendants of the stronger landowners and to the intense migration from Gascony, situated north of the Pyrenees. The creation of new houses and the corresponding population growth increased the competition for the exploitation of natural resources and contributed to the enhancement of the legal and social differentiation between the more powerful (stronger) and the poorer houses. The poorer houses did not pay taxes and had fewer rights and less protagonism in communal affairs. A second crisis occurred in the $17^{\text {th }}$ century, as noted in the decrease in the number of houses, notably strong houses.

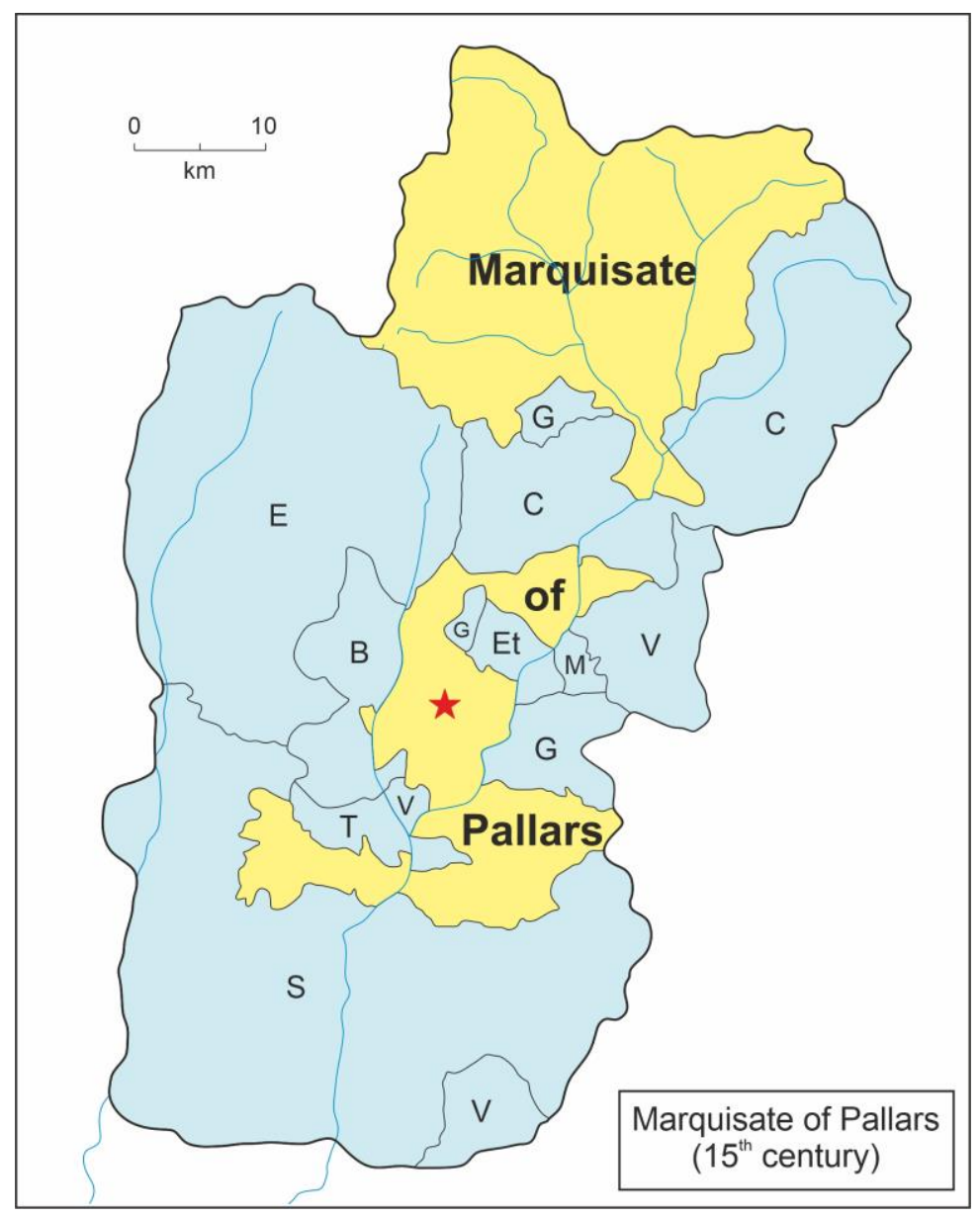

Figure 9. Territorial subdivision of the Pallars region at the beginning of the Modern Age (late $15^{\text {th }}$ century). The Marquisate of Pallars is the yellow area. The blue areas correspond to territories owned by other manors. B = Bellera, $C=$ Castellbò (viscounty), $\mathrm{E}=$ Eril (barony), Et = Estac (barony), $\mathrm{G}=$ Gerri (abbey), $\mathrm{M}=$ Copons de Malmercat (barony), $\mathrm{S}=$ Smaller manors, $\mathrm{T}=$ Torella, and $\mathrm{V}=$ Vilamur (viscounty). The red star indicates the location of Lake Montcortès. Redrawn and modified from Bringué (2005). 


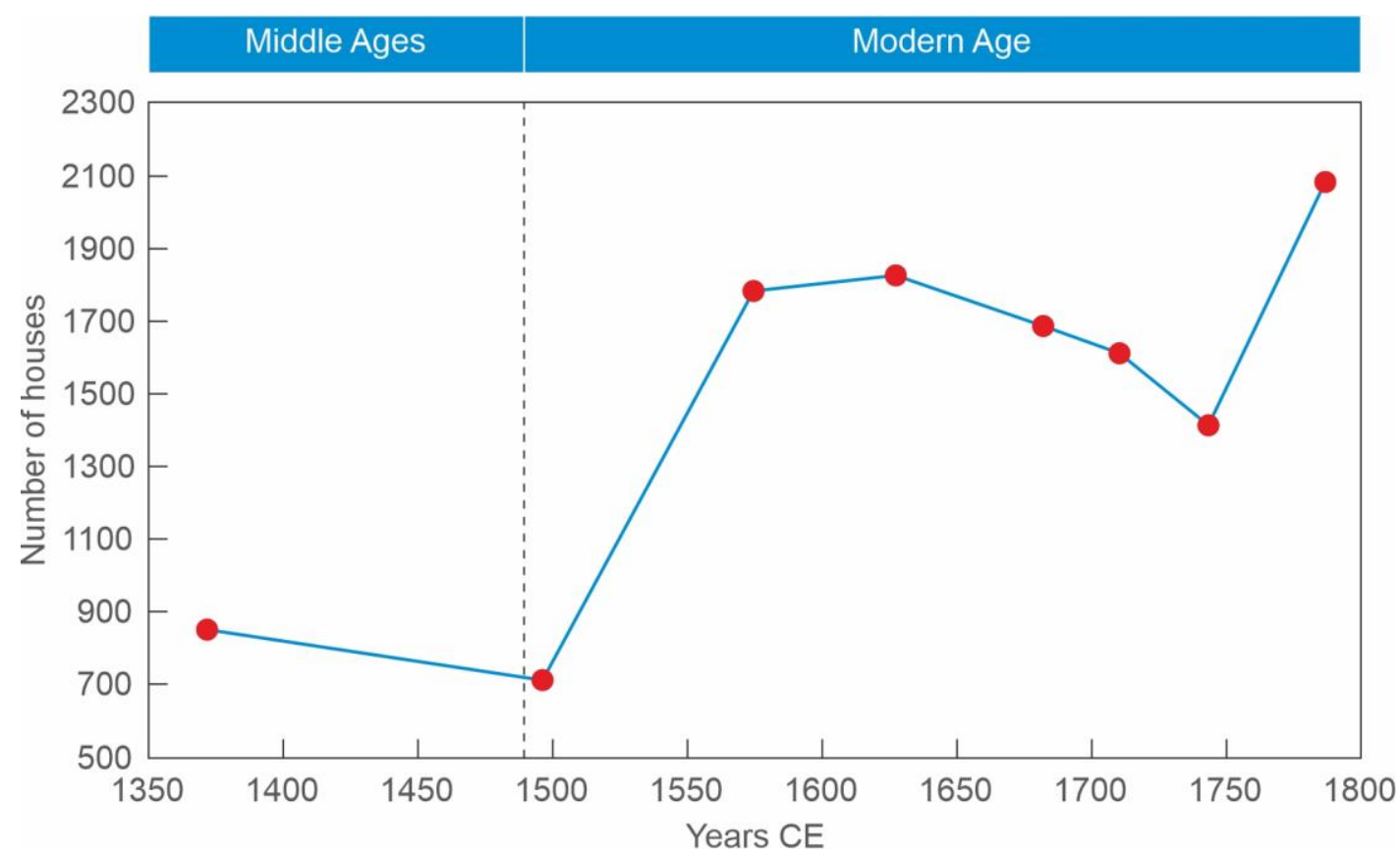

Figure 10. Population evolution in the Pallars region during the Modern Age, after the late Medieval crisis. Based on original data from Bringué (2005).

During the $18^{\text {th }}$ century, the conflicts between the duke and the king aggravated the crisis, which reached its maximum in $1744 \mathrm{CE}$. Further recovery began in $1750 \mathrm{CE}$, with the rehabilitation of the houses lost during the $17^{\text {th }}$ century and the addition of new ones, thus exceeding the number of houses of the $16^{\text {th }}$ century. However, the population numbers of the $11^{\text {th }}$ to $13^{\text {th }}$ centuries, before the late Medieval crisis, were never reached again.

\section{Institutions}

The great territorial fragmentation of the Pallars region during the $15^{\text {th }}$ and $16^{\text {th }}$ centuries (Fig. 9) implied an important jurisdictional complexity. The duke of Cardona and marquis of Pallars never lived in the Pallars and ruled these lands through a governor, also known as a general procurator, who was the maximum political, legal and administrative authority of the marquisate. The remaining territories were ruled by local laic or ecclesiastic authorities, but politically, they were part of a superior royal structure known as the sotsvegueria of Pallars. Two elements that differentiated the Pallars region from the rest of Catalonia were a land-property system called franc alou (complete domain) and the persistence of the communal exploitation system. Under the system of franc alou, the property of the land was totally in the hands of local owners, who only paid taxes to the marquisat or the crown, depending on the region and the economic power of the different houses. These local owners were grouped in communities. The land was subdivided into terms (termes), which were ruled by the communities that controlled the development of activities such as land selling/renting, cultivation and grazing strategies or forest exploitation, among others, and defended the community and its collective rights. This communal system was submitted to controversies and pressures, mainly in the $16^{\text {th }}$ and $18^{\text {th }}$ centuries, but it lasted until the $19^{\text {th }}$ century when liberalism took the lead. In summary, in contrast with the already extinguished feudal system, the communities were truly administrative, political and legal institutions that controlled the land and its usage during most of the Modern Age.

With the incoming of the Bourbon dynasty and the Nueva Planta decree (1716 CE), which abolished the traditional institutions of the Aragonese kingdom, in general, and of Catalonia, in particular, the peculiarities of the Pallars institutions, especially their political and jurisdictional capacities, were revoked. However, the franc alou property system and the collective exploitation of communal goods remained. These local privileges were better protected in the marquisate of Pallars, as they were 
commonly defended by marquises against monarchic interests. However, the situation significantly changed in the 1770s, when the franc alou system was also called into question, paving the way for a new socioeconomic order that led to the precapitalist system.

\section{Economy}

\section{Crops}

Cereals were the main crop, of which wheat was the most extensive, followed by barley and oat. As in most Catalan territories, cereal cultivation constituted the main basis of subsistence. The primary difference between the northern valleys and the southern watersheds was olive and vine cultivation. Olive was mostly cultivated in the southern lowlands, with a northern boundary oscillating around Gerri (Fig. 2). Grape cultivation was more extended and reached valleys such as Llavorsí but was more frequent south of Sort (Fig. 2). The distribution of livestock (notably sheep and pigs) showed opposite patterns, as pastures were more frequent in the northern valleys. In the $17^{\text {th }}$ and $18^{\text {th }}$ centuries, a shift toward productive diversification occurred, as manifested in the transformation of crop fields into pastures, a progressive substitution of cereals by legumes, a gradual replacement of wheat by rye, a decline in grape cultivation in the northern valleys and an important increase in the rearing of livestock. The development of these activities has been linked to the crisis initiated in the $17^{\text {th }}$ century.

\section{Livestock}

Raising livestock on communal lands was an important source of economic wealth. Horizontal transhumance was frequent, and sheep flocks of 20-40 thousand heads moving over long distances were not unusual. Sheep farming was mainly practiced for selling goods such as meat, wool and dairy products, whereas cattle were destined for field labor and transport. Horses were reserved for nobility, and their commerce was strictly controlled. The community that owned the pastures determined the lands to be used for pasture and for transhumance, as well as the grazing load and timing. The conflicts among terms of ownership and use of pastures and animals were also resolved by the involved communities. However, some attempts to change this exploitation model occurred in the $18^{\text {th }}$ century, when some strong houses circumvented the communal organization and appealed directly to the king to increase their privileges for pastures. Actually, these strong houses (including the nobility) were the main livestock owners, whereas poor houses had little or no livestock. For this reason, long-distance transhumance, an expensive and complex activity necessary to secure winter grazing, was also reserved for powerful houses or associations of middle houses, in combination with major pasture owners.

\section{Forests}

In contrast to pastoralism, wood exploitation from forests was an individual activity performed by each house, whose access to the woodlands was considered necessary for subsistence. Forests were exploited for wood needed for the construction and repair of individual (houses, corrals, cabins) or collective (bridges, churches and other public buildings) infrastructures and for commercialization in alien regions. These activities were free but subjected to community rules. Forests were also used to obtain wood for fire and illumination and charcoal and food for livestock. In some cases, forests were partially cut down or burned for temporary cultivation or to develop pastures.

\section{Land renting}

Pastures and forests were also used for business by allowing their use by foreign operators in terms of exploitation licenses, renting or selling. Summer mountain pastures were often leased to external livestock owners for transhumant practices. Wood extraction was also a usual commercial practice in which a fixed amount of wood from a given forest was leased or sold during a given time. All these 
activities, including downward wood transport along the rivers, were strictly controlled by the community until the $18^{\text {th }}$ century when the Nueva Planta decree transferred all privileges to the crown. The situation, however, reversed toward the end of the same century, when the communities recovered their previous rights to the exploitation, transport and commercialization of the wood. Forest regeneration was usually favored, and the danger of deforestation was mainly linked to land clearing for agriculture and, to a lesser extent, to charcoal production for the metallurgic industry.

\section{Other natural resources}

In addition to forests and pastures, other natural resources controlled by the communities were salt, iron, lime, hydraulic power, hunting and fishing. Salt and iron industries were especially important, as they largely contributed to the consolidation of collective affairs over individualistic interests. In the case of salt, communal rights were maintained during the $16^{\text {th }}$ and $17^{\text {th }}$ centuries but were also extinguished at the beginning of the $18^{\text {th }}$ century, when the crown usurped the salt flats and incorporated them into the royal patrimony. In contrast, the iron industry, largely associated with charcoal production and the development of forges, contributed to the recovery of some communal institutions that had been abolished by the Nueva Planta decree in 1716. In the Pallars region, iron exploitation is believed to have been active during the $16^{\text {th }}$ and $17^{\text {th }}$ centuries but is poorly documented. In the late $17^{\text {th }}$ century, the number of documented forges increased, and the techniques of mineral extraction from ores experienced significant improvements, mainly under the lead of private owners. In the mid- $18^{\text {th }}$ century, the communities reached an agreement with private owners, and a mixed production system was established, which was the onset of a time of splendor of the iron industry and the construction of numerous forges. This increased the need for charcoal and the danger of deforestation, a strong concern of the communities, which reinforced their industrial capacity by building new forges and creating, in 1800, a union that included a significant number of villages and public societies of the region.

\section{Commerce}

A milestone for the development of commerce in the Pallars region was the opening, in 1687, of the new pathway of Collegats, which crossed the natural barrier of the Montsec Range, situated to the south (Fig. 3). This facilitated commercial interchange with the southern lowlands and the extra Pyrenean lands, in general. In the north, new commercial activities were established with French towns situated beyond the Pyrenees. Important products were iron, wine, oil and other groceries. Wood and other products were transported downstream by rivers to larger towns of the southern lowlands (e.g., Lleida), including large coastal cities such as Barcelona (Fig. 2).

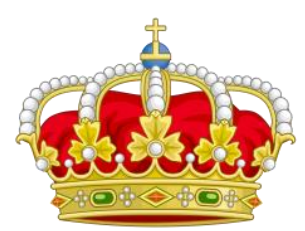




\title{
CONTEMPORARY TIMES
}

\author{
(1789-2005)
}

Farràs (2005) subdivided the latest two centuries of Pallars socioeconomic history into five main phases: 1 ) traditional precapitalist society (late $18^{\text {th }}$ century to 1870$) ; 2$ ) the crisis of the subsistence economy (1870-1910); 3) the transition of traditional society to modern society (1910-1960); 4) the second crisis as a consequence of the Industrial Revolution (1960-1980); and 5) modern capitalist society (1980-2005). As done in the preceding chapter, a synthesis of the main political phases is provided to situate the former socioeconomic phases in a proper historical context (Box II).

\section{Box II. Political chronology of Contemporary Spain}

The French occupation and the independence war (1808-1813). In 1807, the French Emperor Napoleon Bonaparte occupied Spain using as a pretext the invasion of Portugal, which had been previously agreed with the Spanish government, and named his brother Joseph King of Spain, in 1808. This precipitated a popular revolt and the beginning of the Spanish Independence War, which ended in 1813 with the defeat of the French army by a Spanish-Anglo-Portuguese alliance.

Return to the Bourbon monarchy (1813-1868). The French occupation was a short (6 years) ephemeral phase within the Bourbon monarchy, which continued with the son of Carlos IV, Fernando VII, who reigned between 1813 and 1833, when he died. Fernando VI was succeeded by his daughter, Isabel II, who reigned until 1868, although the crown was temporarily in hands of two regents until 1844, when Isabel came of age and governed the country personally. The first financial crisis of Spanish capitalism broke out in 1866 and was followed by a subsistence crisis between 1867 and 1868 due to poor harvests during these years. The sum of these two crises affected businessmen, politicians and popular classes, leading to a general socioeconomic crisis, which ended in a revolution that inaugurated the so-called Sexenio Democrático.

The six-year democracy and the first republic (1868-1874). In 1868, a military revolt broke out that ended the reign of Isabel II, who was dethroned and exiled. A provisional government was established that called for democratic elections for the first time to form constituent courts to draft a new constitution. The democratic parliament was dominated by monarchists, and the new constitution was a monarchic constitution that required a new king. After voting, the parliament elected Amadeo I, of the Italian house of Savoy, who reigned between 1871 and 1873, when he abdicated due to the difficulty of achieving a stable government. Immediately after, the parliament abolished the monarchy and declared the First Spanish Republic, which barely lasted a year, until 1874, when the Bourbon monarchy was restored.

The Bourbon restoration (1875-1931). After the failure of the First Republic, the Bourbon dynasty returned with the son of Isabel II, Alfonso XII, who reigned until his death, in 1885. At that time, there were still six months until the birth of his son and heir, Alfonso XIII, so Alfonso XII's wife, María Cristina of Habsburg, remained as regent until Alfonso XIII came of age in 1902. The political regime continued to be a parliamentary monarchy. During this period, by 1898 , Spain lost its last colonies in America and the Pacific region, retaining only some African possessions. During the First World War (1914-1918), Spain remained neutral, but this, together with the difficult postwar conditions, had important social, economic and political consequences that caused the crisis of the restoration period, which ended with the dictatorship of Primo de Rivera (1923-1930). Between 1927 and 1929, another economic crisis occurred that, in addition to the repressive attitude of the government, caused the union of the parliamentary opposition and the establishment of the Second Republic.

The Second Republic (1931-1936). In 1931, the Republican Party won municipal elections in the main cities and proclaimed the Second Spanish Republic, during which the Catalan Republic was declared by Francesc Massià and the Statute of Autonomy of Catalonia was approved. In 1936, the Popular Front, a coalition of left-wing parties including republicans, socialists and communists, won elections, which precipitated the violent reaction of totalitarian fascists and nationalists, leading to the Spanish Civil War.

The civil war (1936-1939). This war started with the uprising of Francisco Franco from Africa, who commanded the so-called Movimiento Nacional (National Movement), aimed at seizing power quickly, but the successful republican resistance in major cities (Madrid, Barcelona, Valencia) meant the beginning of a prolonged civil war across the country. The war was decided in 1939, when Barcelona and Madrid were submitted by the national front. This signified the beginning of the Franco dictatorship.

The Franco dictatorship (1936-1975). Francisco Franco, who proclaimed himself Head of State, ruled Spain from the end of the civil war (1936) until his death in 1975. The political regime, known as franquismo (Francoism), was a totalitarian military dictatorship whose main ideological bases were Spanish nationalism, Catholicism, fascism and anticommunism. Franquismo was also contrary to any type of social or political freedom and, hence, to democracy and the separation of political, executive and legislative powers. The former democratic parliament was transformed into a pseudodemocratic institution with a single party, the Movimiento Nacional, which followed the rules of the dictator. Fundamental civil rights were also restricted or abolished, and independence and regionalist movements, notably those from Catalonia, were banned and persecuted.

The modern democracy (1975-present). Franco had to die for democracy to return to Spain, but he had already designated his successor Head of State six years before his death. The chosen person was Juan Carlos of Bourbon, who became King Juan Carlos I. A provisional government was designated in 1976 to reform political law, call democratic elections (1977) and draft a new constitution (1978). The new Spanish democracy was consolidated in 1982. The parliamentary monarchy had returned with the same dynasty (the Bourbons) on the throne, a situation that is still ongoing with the son and successor of Juan Carlos I, Felipe VI, as the king. Therefore, the Bourbon dynasty, who began to reign in Spain three centuries ago, has continued to retain the crown. 
Before describing the socioeconomic phases of the contemporary Pallars defined by Farràs (2005), a chronological comparison between these phases and the Spanish political history disclosed in Box I is provided for reference (Fig. 11).

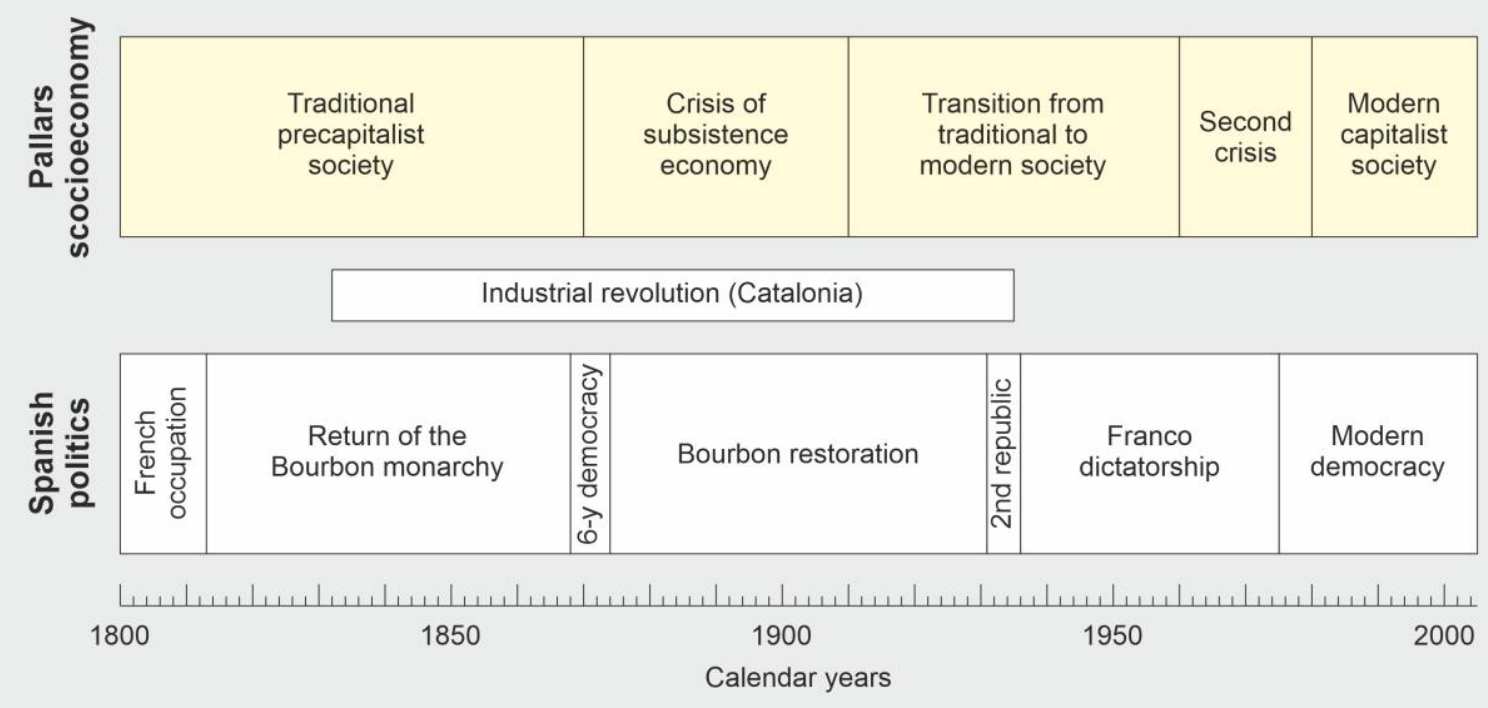

Figure 11. Chronological comparison between Spanish political history and Pallars socioeconomic developments of the $19^{\text {th }}$ and $20^{\text {th }}$ centuries, according to Farràs (2005). The phase corresponding to the Catalan industrial revolution is also indicated.

\section{Traditional precapitalist society (late $18^{\text {th }}$ century to 1870 )}

This phase was characterized by the physical isolation of the Pallars region, the predominance of the subsistence economy and the maintenance of a system of traditional values. Until the mid-19 century, the main pathways of the region were those used for livestock transhumance and bridle paths used for the transportation of merchandise and people. Internal circulation by these pathways was important, and the traditional physical isolation of the Pallars refers to its relative disconnection from the outside. This isolation favored the internal diversification of production to increase self-sufficiency and minimize the dependence of other regions.

Inside the Pallars, two main well-differentiated regions existed: the southern basin and the northern mountains (Fig. 3). The basin had a surplus of commercial products such as wine and olive oil, as vineyards and olive groves had replaced cereals, forests and vacant fields since the end of the $18^{\text {th }}$ century. As a consequence, cereals, mainly wheat, did not meet local needs and had to be imported from neighboring regions. Other products, such as legumes, vegetables, potatoes, hemp or tree fruits, were aimed at covering local self-consumption needs. The same occurred with livestock (sheep herds, draft animals, pigs, fowl). In contrast, the mountains had a surplus of sheep, draft animals and wood, and these products were exported outside the region, including the Catalan littoral and France, often using trunk rafts able to navigate large rivers (Garona, Noguera Pallaresa). As in the basin, other products were intended to cover only local needs.

Among the traditional (preindustrial) manufacturing activities, only iron production and salt extraction were suitable for external commercialization. The centers of these industries were located in the northern High Pallars (iron) and Gerri de la Sal (salt). The production of food, textile fibers and construction material was only for internal self-consumption. The main food industry was related to transformative activities to obtain flour, olive oil and wine. The main textile products were wool, linen, hemp and leather. The extractive industry was based on forests (wood, charcoal) and mineral deposits, either metallic (iron, copper) or not (lime, gypsum, lignite). 
Commercial activities were structured around three main spatial domains: local, intraregional (basinmountain) and supraregional (or external) markets. The local market was restricted to individual valleys or small areas, and the main products were the few surpluses produced by the local subsistence economy. In the intraregional market, the basin and the mountain interchanged their surplus, that is, olive oil and wine, on the one hand, and wood, wool, iron, leather and livestock, on the other. In the supraregional market, the Pallars region exported several products to the rest of Catalonia and Aragon (wool, iron, wood, charcoal, leather and draft animals) and imported others, such as fish, rice and goods, from overseas colonies. The nearby French territories were also part of the supraregional market.

The so-called traditional values were organized around three main social frameworks: the family (house), the town (neighborhood community) and the supramunicipal sphere. The family/house represented the conjunction of three environments (architectural, residential and economic) working as a single unit. Each house was commonly inhabited by three or four generations of the same family, which guaranteed the preservation of three main functions of the traditional family: the transmission of the name, the continuity of the house and the indissolubility of heritage. Economically, the house was the basic production and consumption unit, with a fixed social and sexual division of labor. The town was the core of traditional society and the physical place where most people remained during their whole lives, from the cradle to the grave. In the towns, economic life was organized around a small commercial network (shops, butcheries), jobs (blacksmith, carpenter, shoemaker, barber) and liberal professions (doctor, teacher, notary), which offered basic services. Street life was very active, and religious commemorations constituted singular events that broke the daily working routine. The main supramunicipal activities were the weekly market, aplecs (popular or folkloric meetings) and annual fairs.

\section{The crisis of the subsistence economy (1870-1910)}

The foundations of traditional society began to weaken in the late $19^{\text {th }}$ century, and by the beginning of the $20^{\text {th }}$ century (1910), Pallars had lost a third of its population. This population crisis has been attributed to several factors. First, the Pallars crisis was one more manifestation of the Spanish and European crisis of the end of the $19^{\text {th }}$ century (Box II) due to the intrinsic failure of the subsistence economic system. In the Pallars, this crisis was aggravated by the confiscation of communal goods and properties, which were sold to private owners. Second, unfavorable climatic conditions caused a succession of poor harvests between 1893 and 1896 and an increase in the prices of basic products. Third, the grape phylloxera infected the vineyards of the southern basin in 1900, which caused the loss of the main source of wealth of this area and a significant decline in the commercial relationships with the mountains and the basin.

This crisis deeply affected the poorer and more isolated population sectors, which would have caused a demographic crash. However, the main cause of the depopulation was the emigration of the Pallars people to other regions of Catalonia and to southern France. At the beginning, these emigration movements were seasonal in the search for temporary jobs, but over time, the destinations were more definitive. One of the main targets for permanent settlement was Barcelona, where the emigrants found jobs in industry, domestic service or small commercial activities. However, the main destination of the Pallars emigrants was South America, notably Argentina.

Another reaction to the population crisis was the emergence of local and external initiatives to modernize the region. This modernization included three main aspects: infrastructure, social activities and politics. A milestone in this process was the building, in the late $19^{\text {th }}$ century, of a road between Gerri and the southern lowlands through the Montsec Range (Figs. 2 and 3), which ended the traditional Pallars isolation. This route enabled the establishment of a regular bus service between 1908 and 1912, which significantly improved external communication. The most important towns of 
the region underwent significant urbanistic changes, and domestic and collective services such as water, electricity, telegraph or sewer systems were put into operation during the last decade of the $19^{\text {th }}$ century. The main social initiatives were the creation of various periodicals and a diversity of cultural, economic and political associations, including initiatives for citizen vindication and mobilization. Politically, the representatives (deputies) of the Pallars region had traditionally been foreign people imposed from the central Spanish government with the support of local chieftains. This changed in 1907 when Pallars deputies began to be local politicians.

\section{The transition to modern society (1910-1960)}

A new economic model suddenly appeared with the construction of the first hydroelectric power stations between 1911 and 1916. These stations were promoted and ruled by companies and capital from outside the Pallars region, which lost control over one of its most important natural resources. The development of the electric sector boosted multiple transformations, including the halting of the migratory flux, the improvement of the communication and transport network, the injection of external capital and the creation of new job positions, the reactivation of the commercial and service sectors, and the social modernization of new life forms. This transition to capitalism was more rapid in the Pallars Jussà. In Pallars Sobirà, an additional factor was the modernization of farming practices, with the definitive abandonment of the traditional subsistence economy and the integration of mountain areas into the market economy. The most important manifestation of this process was the progressive replacement of the beef sector with the sheep sector, which led to the incoming and development of the dairy industry by cooperative and private companies. Wood exploitation remained important, but its transport system changed from rafts to trucks due to the construction of a system of river reservoirs.

The modernization process culminated during the second republic (1931-1936), but the civil war (19361939) and the ensuing postwar period under the Franco dictatorship (Box II) represented a profound regression in this trend toward modern society. During those times, the Pallars was significantly impoverished, but some specific signs of recovery began to appear in the 1950s with the revitalization of mining exploitation, the construction of new hydroelectric stations and the arrival of railways to the most important towns, which improved the transportation of commercial materials.

\section{The second crisis (1960-1980)}

In the 1960s, the industrialization of the large urban areas of Catalonia and the mechanization of farming activities determined the massive emigration from rural to urban environments. In the Pallars, the numbers were catastrophic. If we compare the demographic peak that occurred in 1860 (ca. 46,000 people) with the present situation (ca. 19,000), approximately $60 \%$ of the Pallars population has been lost. This has led to the physical disappearance of many towns and villages. Only medieval demographic crises are comparable in magnitude to this situation. Socioeconomic modernization, however, did not stop, and the agrarian structures lost their local/regional character and became more dependent on the central Spanish state and even international interests. This economic reconversion led to the substitution of traditional crops (vineyards, olive groves) by others (almond) and the development of intensive livestock raising (pigs, cow, chicken). Some industrial, mostly textile, and tourist activities also developed during this period. Other indicators of modernization were the widespread penetration of the mass media (radio, TV, press), the revolution of the personal car and the opening to foreign countries and cultures as a result of migrations and the beginning of the tourist industry. As a result, the traditional concept of family/house described above was abandoned due to architectural, organizational and productive reasons. Toward the end of this crisis, the Franco dictatorship ended, and a progressive return to political and civil rights began (Box II). 


\section{The modern capitalist society (1980-2005)}

At present, the same difference observed above between Pallars Sobirà, where economic recovery is faster thanks to tourism, and Pallars Jussà remains. It has been argued that Pallars is now dedicated to producing amusement for urban consumers and that the environment and the natural resources of the region will progressively lose their traditional economic activities (farming, forestry) to become the main target of tourist activities. This is already occurring, and it is unclear whether this is the only option or whether there are other models to be considered for a more sustainable, diversified and balanced exploitation.

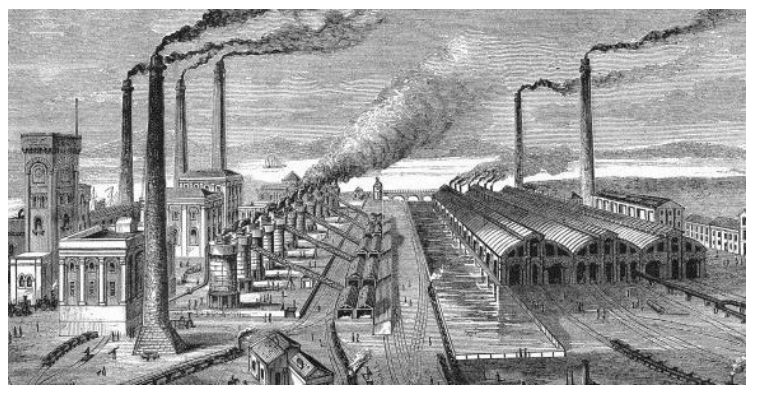




\section{References}

Bringué, J.M. 2005. L'edat moderna. In: Marugan, C.M. \& Rapalino, V. (eds.), Història del Pallars. Dels Orígens als Nostres Dies. Pagés Editors, Lleida, pp. 87-119.

Cots, P. 2005. Els pobles de la prehistòria I I'antiguitat. In: Marugan, C.M. \& Rapalino, V. (eds.), Història del Pallars. Dels Orígens als Nostres Dies. Pagés Editors, Lleida, pp. 13-43.

Farràs, F. 2005. El Pallars contemporani. In: Marugan, C.M. \& Rapalino, V. (eds.), Història del Pallars. Dels Orígens als Nostres Dies. Pagés Editors, Lleida, pp. 121-144.

Marín, M. 1995. Atlas Histórico. Editorial Marín, Barcelona, 294 pp. Edición especial para Encyclopaedia Britannica Publishers, Inc.

Marugan, C.M. \& Oliver, J. 2005. El Pallars medieval. In: Marugan, C.M. \& Rapalino, V. (eds.), Història del Pallars. Dels Orígens als Nostres Dies. Pagés Editors, Lleida, pp. 45-86.

Marugan, C.M. \& Rapalino, V. 2005. Història del Pallars. Dels Orígens als Nostres Dies. Pagés Editors, Lleida, $188 \mathrm{pp}$.

Rull, V., González-Sampériz, P., Corella, J.P., Morellón, M., Giralt, S. 2011. Vegetation changes in the southern Pyrenean flank during the last millennium in relation to climate and human activities: the Montcortès lacustrine recod. Journal of Paleolimnology 46, 387-404.

Rull, V., Vegas-Vilarrúbia, T., Corella, J.P., Trapote, M.C., Montoya, E. \& Valero-Garcés, B. 2021. Vegetation and landscape dynamics of the central pre-Pyrenees during the last 3000 years. Palaeogeography, Palaeoclimatology, Palaeoecology 571, 110392.

Trapote, M.C., Rull, V., Giralt, S., Montoya, E., Corella, J.P., Vegas-Vilarrúbia, T. 2018. High-resolution (subdecadal) pollen analysis of varved sediments from Lake Montcortès (southern Pyrenean flank): a fine-tuned record of landscape dynamics and human impact during the last 500 years. Review of Palaeobotany and Palynology 259, 207-222. 